\title{
Hizmet Kalitesi, Tatmin ve Güvenin Daha Fazla Ödeme Eğilimi Üzerindeki Etkileri
}

\author{
The Effects of Service Quality, Satisfaction, and Trust on \\ Willingness to Pay More
}

\section{Yrd. Doç. Dr. Emre Şahin Dölarslan - Doç. Dr. Alper Özer}

\section{Öz}

İşletmeler, müşterilerinin kendilerini tercih etmesini ve bu tercihin uzun süre devam etmesini isterler. Bu tercih işletmenin riskini azalttığ gibi, karlllkları üzerinde de olumlu etkiye sahiptir. Benzer șekilde, tüketiciler de algıladıkları riski düşürebilmek için beklentilerine karşllk veren isletmeleri ve markaları tercih ederler. Bazı durumlarda da ürün veya hizmetlerin niteliğine göre, belirli düzeylerde daha yüksek fiyat ödemeyi kabul ederler. Bu çalışma ilk olarak tüketicilerin daha fazla ödeme eğilimlerini ve bu eğilimin belirleyicileri olarak hizmet kalitesi, tatmin ve güven unsurlarm teorik olarak incelemektedir. Sonrasinda söz konusu faktörler ile daha fazla ödeme eğilimi ilişkilendirilmekte ve hipotezler oluşturulmaktadır. Teorik altyapı, sağlık hizmetleri ile de ilişkilendirilmekte ve sağlı hizmetlerinin ayr dinamikleri ortaya konulmaktadır. Araştırma modelinin analizinde veriler kolayda örneklem yöntemiyle belirlenmişörneklemden anket yöntemi ile toplanmıştır. Sadece Sosyal Güvenlik Kurumu'na mensup, 437 cevaplayıcıdan elde edilen verilerle model, yapısal eşitlik modellemesiyle analiz edilmiş ve belirleyicilerin etkileri ölçülmüştür. Çalışmada ayrica özel hastane ve devlet hastanesi tercihinin düzenleyici etkisi ortaya konulmaktadır. Araștırma bulgular, hizmet kalitesi, tatmin ve güvenin yüksek olmasının, sağllk hizmetleri talep eden tüketicilerin daha fazla ödeme eğilimini olumlu şekilde etkilediğini göstermektedir. Ayrıca, hastaların özel veya devlet hastanesi seçiminin, model kapsamındaki ilişkiler arasında düzenleyici etkisi olduğu ortaya çıkmıştır.

Anahtar Kelimeler: Daha Fazla Ödeme Ĕ̈ilimi, Hizmet Kalitesi, Tatmin, Güven, Sağlık Sektörü

\begin{abstract}
Companies will seek customers who will stay with the company for longer times. Customer retention will give the companies a chance to reduce their risks and have the opportunity to increase their profits. Customers, as well, desire to repurchase brands while they are satisfied with the current products or services, in order to reduce their perceived risks of buying. In some cases, in order to reduce these risks, customers accept to pay more for the product or services. This study first explains the willingness to pay more, and then theoretically explores the determinants of the willingness to pay more. A theoretical background was being established for service quality, satisfaction and trust effecting willingness to pay more, considering health services. 437 patients were interviewed with a questionnaire. The data were analyzed using structural equation modeling and effects of determinants were measured on willingness to pay more. Mediating effect of preference on state and private hospitals on the relationships was also measured. Findings show that higher perceived service quality, satisfaction and trust have a positive on the effect willingness to pay more for health services. In addition, it has been found that the preference for state and private hospitals moderate the relationships between the dimensions and the willingness to pay more.
\end{abstract}

Keywords: Willingness to Pay More, Service Quality, Satisfaction, Trust, Health Sector

Yrd. Doç. Dr. Emre Şahin Dölarslan, Çankırı Karatekin Üniversitesi İİBF İşletme Bölümü, esdolarslan@gmail.com Doç. Dr. Alper Özer, Ankara Üniversitesi Siyasal Bilgiler Fakültesi İșletme Bölümü, ozer@politics.ankara.edu.tr 


\section{Giriş}

Küresel boyutta olduğu kadar Türkiye'de de, sağllk hizmetlerinin sunumunda piyasa yönlü bir değişim yaşanmaktadır. Sağlık sektöründe yaşanan yapısal değişimin sonucu olarak Türkiye'de, kamu sahipliğindeki hastanelerin yanı sıra özel sağlık kuruluşlarının da mevcut sağlık sisteminin sürdürülebilir bir șekilde yürütülmesi açısından önemi her geçen gün artmaktadır. Günümüz koşullarında, hastaların sağlık kuruluşu seçimlerinde çok sayıda alternatif sağlayan bu sistemin finansmanının bir kısmı, sistemin sürdürülebilirliğini sağlamak açısından, hastalardan talep edilen ek muayene ve tedavi ücretleri ile desteklenmektedir. Bu koşullar altında hastalar için sağlık hizmeti alacakları kurumun tercihi, bir anlamda satın alma davranışına dönüşerek, bu davranışın tüketici temelli bir karar süreci ile eşleştirilebilmesine olanak tanımaktadır.

Hizmet pazarlaması perspektifinde, sadakat oluşumu kapsamında davranışsal bir çıktı olarak değerlendirilen daha fazla ödeme eğiliminin belirlenmesinde, kalite ve ilişkili kavramlar üzerinde temellenen çalışmalar bulunmaktadır. Benzer şekilde, sağlık hizmetleri literatüründeki çalışmalarda da, ağırlıklı olarak kalite ve ilişkili kavramlar çerçevesinde değerlendirmeler yapıldığı görülmektedir. Hâlihazırda, Türkiye sağlık sisteminde de, sağlık sisteminin ücretlendirmesinde sağlık kuruluşlarının Sağlık Bakanlığı tarafından belirlenen kalite düzeyleri dikkate alınmaktadır.

Sağlık hizmetlerinin kalitesi ve performansı arasındaki ilişkinin sektörel açıdan önemini ortaya koyan çalışmalar (örn., Mechanic, 1998; Magee vd., 2003), sağlık hizmetini sunan kurumun performansı ile hastane seçimi arasında belirleyici bir ilişkinin varlığından söz etmektedir. Bu kapsamda, hastaların ödeme eğilimlerinin belirlenmesinde kalite ve ilişkili kavramların yanı sıra, hizmet sunan kurumun niteliği de önem kazanmaktadır. Ancak ilgili literatür incelendiğinde, hastaların sağlık kurumları tercihinde daha fazla ödeme eğilimlerinin oluşumunu ve bu davranışın, devlet ve kamu hastaneleri açısından farklı yönlerinin değerlendirilmesi içeren bir çalışmaya rastlanmamaktadır. Bu nedenle çalışma kapsamında, hastaların daha fazla ödeme eğilimlerinin oluşumunda belirleyici olan etkenler arasındaki etkileşim, bütüncül bir model kapsamında ele alınarak, kamu ve devlet hastaneleri açısından farklılaşan yönleri ile değerlendirilmesi amaçlanmaktadır. Çalışmanın, literatüre olduğu kadar sağlık hizmetleri sektörüne ve
Türkiye özelindeki uygulamaya önemli katkılar sağlayacağı düşünülmektedir.

Çalışma genel olarak tüketicilerin daha fazla fiyat ödeme eğiliminin ne olduğunun incelenmesiyle başlamaktadır. Bu noktada, daha fazla ödeme eğilimi genel olarak incelenmekte, sonrasinda ise daha fazla ödeme eğiliminin belirleyicileri değerlendirilmektedir. Bu belirleyiciler algılanan kalite, tatmin ve güven olarak incelenmektedir. Söz konusu belirleyiciler ilk başta genel hatlarıyla ele alınmakta, sonrasında da daha fazla ödeme eğilimi ile ilişkilendirilmektedir. Benzer ilişkilendirmeler hipotezlerin oluşturulmasında da teorik altyapı olarak kurulmaktadır. Çalışma yapısal eşitlik modellemesiyle test edilmekte, model teorik olarak açıklanmaktadır. Uygulama ve uygulama sonucunda elde edilen bulgular çerçevesinde yapılan tartışmalara da son iki bölümde yer verilmektedir. Çalışmanın sonuçlarına, kısıtlarına ve ileride yapılacak çalışmalar için sunulan önerilere ise tartışma ve sonuç bölümünde yer verilmektedir.

\section{Literatür incelemesi}

\section{Türkiye'de Sağlık Politikaları ve Tedavi Ücretleri}

Sağlık hizmetlerinde önceliklerin belirlenmesi sınırlı kaynakların verimli ve etkili dağıtım ve kullanımının temel bir parçası olmakla birlikte, insanların sağlık ihtiyaçları ve talepleri mevcut sağlık hizmetleri miktarından her zaman fazla olmaktadır (Top, 2006, s. 95). Bu nedenle sağlık hizmetlerinin sunumu, finansmanı ve ücretlendirilmesi gibi kritik konularda yaşanan sorunlar, küresel boyutta olduğu kadar, ülkemiz açısından da farklı düzenlemelerin yapılmasını gündeme getirmektedir.

Artan nüfus ile birlikte, ülkelerin sağlık hizmetlerinin niteliğinin ve niceliğinin artırılması ihtiyacı doğmuş, özellikle bütçe açıkları nedeniyle birçok kamu hizmetinin yanı sıra sağlık hizmetlerinin de etkin bir şekilde sürdürülebilmesi için gereken finansmanının sağlanamadığı görülmüş̧ür. Bu nedenle uluslararası kuruluşlar ${ }^{1}$, sağlık alanında özelleştirme uygulamalarını desteklemek suretiyle, birçok ülkenin sağlık poli-

1 Günaydın (2011)'a göre, IMF, UNICEF ve Dünya Bankası gibi uluslararası kuruluşlarca desteklenen reformların ana unsuru, sağlık hizmetlerinin piyasa temelinde yeniden kurgulanması oluşturmaktadır. Bu yeni yapılanmada kamu, sağlık hizmeti sunmaktan çok, sağlık hizmetleri piyasasını düzenleyen, kurallar koyan ve finansman sağlayan bir rol üstlenmekte ve bu şekilde tasarruf edeceği kaynakları, asıl sorumluluğu olan koruyucu sağlık hizmetlerine yönlendirebilecektir. 
tikalarını etkilemektedirler. Bu kapsamda, özellikle piyasa ekonomisi sürecinde sağlık hizmetlerindeki etkililiğin artırılması çabasına ek olarak, hizmet kalitesinin arttırılma çabaları da özelleştirmenin sağlık alanındaki yoğunluğunu arttıran etkenlerdendir (Altay, 2007, s. 33). Türkiye sağlık politikalarında son yıllarda yaşanan değişim, 2003 yılında Sağlık Bakanlığı tarafından uygulamaya koyulan Sağlıkta Dönüşüm Programı (SDP) ile farklı bir boyut kazanmıştır. Bu düzenleme ile sağlık finansmanında tüm kamu finansman kurumlarının birleştirilerek tek bir kamu sağlık finansman kurumu oluşturulması ve Genel Sağlık Sigortası uygulamasına geçilmesi; Sağlık Bakanlığının uygulayıcı özelliğinin, düzenleyici/koordine edici olarak değiştirilerek, yeniden yapılandırılması; kamu hastanelerinin işletme haline getirilmesi; birinci basamakta aile hekimliğine geçilmesi; sağlık çalışanlarının performansa göre ücretlendirilmesi ve istihdamında yeni tercihlerde bulunulması amaçlanmıştır (Soyer, 2009, s. 179). Devlet Memuru ve Emekli Sandığı mensuplarına, sevk zincirine dâhil olmadan özel hastanelere başvurma olanağı getiren bu düzenleme (Sülkü, 2011, s. 7) ile özel hastanelerin sayısı da hızlı bir şekilde artış göstermiştir (YASED, 2012, s. 30).

Günümüz Türkiyessinde, kamu ve özel hastanelerde sunulan sağlık hizmetlerinin finansmanında en etkili kurum Sosyal Güvenlik Kurumu (SGK)'dur. SGK tarafından hastanelerde yapılan tedavi uygulamaları ve bunlara ilişkin fiyatlandırma işlemleri "Tanıya Dayalı Fiyat Uygulaması" olarak adlandırılmakta ve özel hastanelerde sunulan sağlik hizmeti için SGK'dan alınacak ücretler, kamu hastaneleriyle aynı düzeyde tutulmaktadır. Ancak, hizmet kalitesi yüksek özel hastaneler, hastanın kabul etmesi koşuluyla paket ücretlerin üzerine fark ücreti ekleyerek, bu fark ücretini hastadan tahsil etmektedir (Temel, 2003, s. 18) ${ }^{2}$.

$\mathrm{Bu}$ sistem çerçevesinde, tedavi hizmeti alacak hastalar kamu veya özel hastane tercihlerinde bağımsız olmakla beraber, yapılan düzenleme ile sağlık kuruluşlarının Sağlık Bakanlığı tarafından belirlenen kalite düzeylerinde ulaşılabilir, nitelikli ve sürdürülebilir bir şekilde hizmet alabilmek için daha fazla ödeme yapmak durumunda kalmaktadırlar.

2 SGK, 2011 yılında "Özel Hastanelerin Puanlandırılması ve İlave Ücret Alınması Hakkında Yönerge” yayınlamış ve bu yönerge kapsamında özel hastaneleri Hizmet Kalite Standartlarına (HKS) göre değerlendirerek, belirli bir puanlama sürecine tabi tutmaya başlamıştır (http://www.sasder.org/ozel-hastanelerin2012-puanlandirmasi.aspx Erişim Tarihi: 01.09.2013).

\section{Daha Fazla Ödeme Eğilimi ve Belirleyicileri}

Ekonomistler tarafından Daha Fazla Ödeme Eğilimi (DÖE-willingness to pay more), bir mal veya hizmet satın almak amacıyla tüketicinin ödemeye razı olduğu en yüksek fiyat düzeyi (reservation price) ile eşleştirilmektedir (Homburg vd., 2005, s. 85). Söz konusu bakış açısı dâhilinde, tüketicinin ödemeye razı olduğu en yüksek fiyat düzeyinin oluşumu, tüketicinin mal veya hizmete verdiği değerin bir sonucudur. Bu kapsamda tüketici, mal ya da hizmet alternatifleri arasında seçim yaparken, kendi faydasını maksimum yapacak alternatifi tercih etmektedir (Kalish ve Nelson, 1991; Kohli ve Mahajan, 1991). Bu nedenle tüketicinin ödemeye razı olduğu veya olacağı en yüksek fiyat düzeyi, aynı ürün grubunda yer alan alternatif mal ya da hizmetlere göre bile farklılık gösterebilmektedir.

Pazarlama literatüründe ise DÖE, tüketicinin bir mal ya da hizmet için ödemeye istekli olduğu maksimum para miktarının yanı sıra (Homburg vd., 2005; Wertenbroch ve Skiera, 2002) fiyattaki herhangi bir artışa rağmen tüketicinin satın almaya devam etme isteği (Srinivasan vd., 2002, s. 45) olarak tanımlanmaktadır. Ekonomi bakış açısının sunduğu değer ve fayda mukayesesine ek olarak, pazarlama bakış açısı altında DÖE’nin incelenmesinde tüketicinin psikolojik durumu da dikkate alınmaktadır. Bu paralelde Bolton ve Lemon (1999)'a göre tüketiciler, kullanımdan kaynaklanan ekonomik fayda düzeyinin uygunluğunu, zaman içeresinde devamlı bir şekilde değerlendirmektedirler. Söz konusu değerlendirme, "ödeme dengesi" (payment equity) olarak adlandırılmakta ve bu bakış açısı altında işletme ile tüketici arasındaki değişimin ekonomik maliyeti tüketici tarafından sorgulanmaktadır. Tüketici, bu dengenin kendi açısından sürdürülmesini amaçlarken, yaptığı değerlendirmedeki temel kriteri elde ettiği tatmin düzeyi ile katlanmak zorunda kaldığı ekonomik maliyetlerin kıyaslanmasıdır (Bolton ve Lemon, 1999, s. 171). Söz konusu kıyaslamanın tüketici tarafından sürekli bir şekilde yapılması, işletmenin zaman içerisindeki fiyat ya da kalite düzeyindeki değişimlerinin, tüketicinin sonraki tercihlerine olan etkisini de içinde barındırır. $\mathrm{Bu}$ nedenle tüketici ödeme dengesi, fiyatın ve tüketici tatmin düzeyinin, tüketicinin sonraki kullanım düzeylerinde etkisinin açıklanmasında önemli bir rol üstlenir. Söz konusu dengenin korunması açısından tüketici, kullanımın artması ve azalması olmak üzere iki yönlü davranış sergiler. Bu kapsamda, ödeme dengesi tüketicinin tatmin düzeyi ile yakından ilişkili olması sebebi ile tatmin düzeyi düşük olan tüketici- 
ler, kendileri için adil, doğru ve mantıklı bir dengenin oluşmasına yönelik olarak, düşük fiyat ödeme eğilimi sergilemektedirler (Homburg vd., 2005, s. 85).

Tüketicilerin daha fazla ödeme eğilimleri, ürün ve hizmetlerle, fiyat arasındaki değerlendirmelerine bağlıdır (Simonson ve Drolet, 2004). Fiyata ilişkin algıları da içerecek şekilde, tüketicilerin gerçekleştirecekleri bu değerlendirmeler, satın alınan ürün veya hizmetlerin subjektif değeriyle uygun bir fiyat ilişkisine bağlıdır. Çoğu ürün veya hizmet farklılıklara sahiptir, sağladığı tatmin düzeyinde farklılıklar oluşur, farklı kalite düzeyleri söz konusu olur ve tüketicilerin hissettiği güven duygusu farklılık gösterir. Bu durum, tüketicilerin herhangi bir ürün veya hizmet için daha yüksek fiyat ödeme eğilimini etkiler. Tüketiciler, ürün ve hizmetlerin hangi özelliklerinin bir araya getirilmiş olduğuna ve bu özelliklerle ilişkilendirilmiş olan fiyat düzeyiyle ilgili fiyat değerlendirmelerini buna göre gerçekleştirirler (Simonson ve Drolet, 2004). Daha net bir ifadeyle, daha fazla ödeme eğilimi tüketicilerin satın alma ile ilgili olarak yüklemiş oldukları değerle ilişskilendirilir.

Bunun yanı sıra tüketici davranışı perspektifinde DÖE, davranışsal niyetin ve buna bağlı olan sadakat davranışlarının önemli bir çıktısı olarak görülmektedir. Çok boyutlu bir kavram ve tüketici karar alma sürecinin işletme yönlü en önemli çıtılarından biri olarak kabul edilen marka sadakatinin (Chaudhuri ve Holbrook, 2001; Jacoby ve Kyner, 1973; Morgan ve Hunt, 1994) psikolojik boyutları, işletmeler için stratejik açıdan önem taşımaktadır. Bu kapsamda, tüketicinin gelecekteki davranışlarının tahmin edilmesi açısından iyi bir gösterge niteliğinde olan davranışsal boyutlar (Zhang ve Bloemer, 2008), tüketici ile işletme arasından uzun dönemli bir ilişki kurulabilmesi açısından (Adjei ve Clark, 2010) da önemli bir faktördür. Konu ile ilgili çalışmalar değerlendirildiğinde, marka sadakati oluşumunun tüketici açısından DÖE yanı sıra en önemli davranışsal çıtıllarının, olumlu ağızdan ağıza iletişim (Word of mouth-WOM) ve tekrar satın alma niyeti (repurchase intention-RPI) olduğu görülmektedir (Homburg ve Giering, 2001; Zhang ve Bloemer, 2008). Bu nedenle hizmet sürecini değerlendiren modellerde davranışsal çıktı olarak ele alınan DÖE, işletme karlılığının yanı sıra mevcut hizmetin sürdürülebilirliği açısından da önem taşımaktadır. Zeithaml vd. (1996), yeni müşteri elde etmenin maliyetinin, mevcut müşterileri tutmanın maliyetinden daha yüksek olduğunu ve aldıkları hizmetin kalitesi ve hizmetten elde edilen tatminle işletmeyle kalan tüketicilerin daha yüksek karlılık sağlayacağını ifade etmektedir. Yazarlar bunun temel nedeni olarak uzun süre işletmede kalan tüketicilerin hem ek hizmetler talep edeceklerini, hem de işletmenin söz konusu tüketicilere daha yüksek fiyat uygulayabilmelerini göstermektedir.

Aşağıda tüketicilerin daha fazla ödeme eğilimlerinin belirleyicileri teorik olarak incelenmektedir. Her ne kadar bu belirleyicilerin daha fazla ödeme eğilimlerine etkisi ayrı olarak incelenen konularsa da, aralarındaki ilişkilerin ortaya konulması önem taşır. Örneğin, Gounaris (2005), hizmet sağlayıcı ile müşteriler arasındaki güven unsurunun, hizmet kalitesiyle doğrudan ilişkili olduğunu ifade etmektedir. Güven ve tatmin arasındaki ilişki, tüketicilerin elde edecekleri ürün veya hizmetlerin niteliğine göre de değişiklik gösterecektir. Özellikle sağlık hizmetleri gibi tüketicilerin daha yüksek düzeyde önem yükledikleri durumlarda, ilgilenim düzeyi, güven ve tatmin arasındaki ilişkiyi daha üst seviyelere getirmektedir (Delgado-Ballester ve Munuera-Aleman, 2001). Benzer şekilde Kassim ve Abdullah, (2010) tatmin ile kalite arasında ve müşteri tatmininin güven üzerinde pozitif bir etkisinin olduğunu ifade etmektedir. Araştırmacılar ayrıca, hem müssteri tatmininin hem de müşteri tatmininin daha fazla ödeme eğilimini pozitif şekilde etkileyen sadakat üzerinde etkili olduğunu söylemektedirler. Bunun yanında, tüm bu unsurların daha yüksek ödeme eğilimi yaratan marka sadakati ile ilişkisi de ortaya konulmaktadır. Örneğin, Harris ve Goode (2004), tüketici tatmini ile marka sadakati arasında olumlu bir ilişkinin olduğunu ortaya koymaktadır. Ibanez vd. (2006), hizmet kalitesi, tatmin ve güven boyutlarının tüketicilerin marka değiştirme maliyetleri arasındaki ilişkiyi incelemiştir. Çalışma, tatminin önemli olduğunu, ancak tek başına bağlıllığa yol açan bir etken olmadığını ileri sürmektedir. Söz konusu çalışma, ayrıca, müşteri tatmininin sağlanabilmesi için hizmet kalitesi üzerine odaklanılması gerektiğini ifade etmektedir. Choi vd. (2004) de benzer bir şekilde, hasta tatmininin sağlanması amacının yerine getirilmesine yönelik olarak, hizmet kalitesinin bir sağlık kuruluşunun başarısı üzerinde önemli etkiye sahip olduğunu ifade etmektedir.

\section{Hizmet Kalitesi}

Hizmet kalitesi literatürde geniş bir şekilde inceleme alanı bulmuştur. Araştırmalar yoğun olarak hizmet kalitesiyle işletme performansı, müşteri tatmini ve satın alma eğilimi gibi konuları ilişkilendirmektedir 
(Choi vd., 2004). Araștırmalar, hizmet kalitesinin yüksek veya düşük olmasılya, işletme performansı arasında doğru orantılı ilişkiler bulmuşlardır (Zeithaml vd., 1996). Hizmet kalitesinin yüksekliği tüketicilerin davranışsal eğilimlerini etkilediği için bu tür bir sonuç ortaya çıkmaktadır. Zeithaml vd., (1996), yüksek hizmet kalitesinin olumlu davranışsal eğilime neden olduğunu ifade etmektedir.

Hizmet kalitesinin ölçümü, tüketicilerin aynı hizmeti bir daha talep etmeleri ve algıladıkları hizmet kalitesinin yüksek olması durumunda, daha yüksek bir fiyat ödemeleri ile ilişkilidir. Bu açıdan bakıldığında, kalitenin ölçümü işletmeler açısından önem taşır. Hizmet kalitesi, ölçümünün yanı sıra ilişkili olduğu değişkenler itibariyle de literatürde sıklıkla ele alınan konulardan birisidir. Hizmet kalitesinin ölçümü konusunda Parasurman vd. (1985, s. 47) tarafından yapılan çalışma, hizmet kalitesinin çok boyutlu olarak ele alınması gereğini ortaya koymuş; araştırıcılar, söz konusu boyutları fiziksel özellikler, güvenilirlik, isteklilik, yeterlilik, nezaket, inanılabilirlik, güvenirlik, ulaşılabilirlik, anlayış ve iletişim olmak üzere 10 başlık altında değerlendirmişlerdir.

Hizmet kalitesinin ölçümü ve değerlendirilmesi konusunda çeşitli sektörlerde yapılan çok sayıda çalışmaya konu olan yaklaşımlar bulunmaktadır (Brady ve Cronin, 2001; Dabholkar vd., 1996; Grönross, 1984; Francis ve White, 2002; Loiacona, Watson ve Goodhue, 2002; Parasurman ve ark., 1994; Yoo ve Donthu, 2001; Wolfinbarger ve Gilly, 2003; Zeithaml vd., 2002). Bununla birlikte literatürde algilanan hizmet kalitesinin ölçümünde bazı çalışmalar diğerlerine göre daha fazla öne çıkmaktadır. Ancak, hizmet kalitesi ve tüketici tatminini ölçebilmek için geliştirilen SERVQUAL (Parasurman, vd., 1985, 1988) ve SERVEPERF (Cronin ve Taylor, 1992) modelleri, bu yaklaşımlar arasında en yaygın olarak kullanılanlarıdir (Athanassopoulos, 2000, s. 192)

Algılanan hizmet kalitesi, tüketicinin hizmete dönük beklentileri ile gerçek hizmet performansının karșılaştırılması sonucunda oluşmaktadır. SERVQUAL olarak adlandırılan ölçüm modeli, zaman içerisinde yapılan çalışmalarda boyutların birbirleriyle çok yakın ilişkili olduğunun görülmesi nedeniyle (Papatya vd., 2012, s. 91), Parasurman vd. (1988, s. 6) tarafından revize edilerek somut özellikler (fiziksel özellikler, ekipman ve personelin görünümü), güvenilirlik (sunulan-vaat edilen hizmeti, güvenilir ve doğru biçimde yapma becerisi), heveslilik (müşterilere yardım etme ve hızlı hizmette bulunmadaki isteklilik), güvence (çalışanların bilgi ve nezaketleri ile onların bu özelliklerinin müșterilerde güven uyandırması) ve empati (önemseme; müşterilere sağlanan bireysel ilgi) olmak üzere 5 boyut altında toplanmıştır. Hizmet kalitesinin belirlenmesi amaciyla oluşturulan bir diğer ölçüm modeli ise Cronin vd. (1992) tarafından SERVPERF olarak adlandırılan yaklaşımdır. Cronin vd. (1992), SERVQUAL'dan farklı olarak, hizmet kalitesinin ölçümünde performansa dayalı bir yaklaşımın olması gerektiğini savunmaktadırlar. Söz konusu yaklaşımlar, tüketicilerin talep ettikleri hizmetle ilgili olarak daha fazla ödemeleri için önemli olan algılanan kalitenin belirlenmesi açısından önem taşır. Algılanan kalitenin yüksek olması, tüketicilerin talep edecekleri hizmetler için daha yüksek miktarda fedakarlık gösterebilmeleri için önemli bir gösterge olur ve söz konusu gösterge, işletmelerin algılanan kalite değerlendirmeleri üzerinde etkili olacaktır.

Sağlık hizmetleri, hizmet kalitesinin sıkça değerlendirmeye alındığı sektörlerden biridir. Sağlık hizmetleri temel alındığında, tüketicilerin daha fazla ödeme yapmaları açısından önemli bir etken olan hizmet kalitesinin, sağlık hizmetlerinde nasıl ölçüldüğü ve işletmeler tarafından ne düzeyde dikkate alınaca$\breve{g ̆}_{1}$ ayrı bir önem taşımaktadır. Bazı yazarlar (Brown ve Swartz, 1989; Carman, 2000; Reidenbach, 1990), genel anlamda hizmet kalitesinin ölçüldüğü söz konusu ölçüm modellerinin sağlık hizmetleri için yeterli olmadığı ve uyarlanması gerektiği görüşünü savunurlar. Örneğin Ramasaran-Fowder (2008) özel hastanelerde yaptığı çalışmada, SERVQUAL ölçeğini temel alarak sağlık hizmetlerine uyarlamıştır. $\mathrm{Bu}$ çalışma sonucunda PRIVHEALTHQUAL olarak adlandırılan ve yedi boyuttan oluşan bir ölçüm modeli geliştirilmiştir. Bu ölçeğe göre sağllk hizmetlerinde hizmet kalitesinin boyutları, somutluk/görünüm (fiziksel özellikler, sağlık kurumunun imajı ve görünümü), güvenilirlik/adil ve eşit tedavi (hizmeti güvenilir, doğru ve adil bir biçimde yerine getirme becerisi), heveslilik (hastalara yardım etme ve hızlı hizmette bulunmadaki isteklilik), güvence/empati (hekimler ve diğer personelin, bilgi ve nezaketlerinin hastalarda güven uyandırması; önemseme ve hastalar gösterilen bireysel ilgi düzeyi), temel tıbbi hizmetler/ profesyonellik/ beceri/yeterlilik (hizmetin temel tibbi yönleri: uygunluğu, etkililiği ve hastaya olan faydası; bilgi, teknik uzmanlık, eğitim ve deneyim miktarı) ve ekipman ve kayıtlar (hekimler tarafından kullanılan 
fiziksel ekipman ve hastanın tıbbi geçmişinin hatasız kayıtlanması), bilgi verme (hekim tarafından bilgi verilmesi) boyutları sağlık hizmetlerinde algılanan kalitenin boyutları olarak öne çıkmıştır.

Literatürde algılanan kalite ile tüketicilerin daha fazla ödeme eğilimleri arasındaki ilişki de incelenmektedir Örneğin, Bloemer vd., (1999), hizmet kalitesi ve tüketicilerin yeniden satın alma eğilimleri arasındaki pozitif ilişki ve hizmet kalitesi yüksek olduğunda tüketicilerin daha yüksek düzeyde fiyat ödemeyi kabul edeceklerini temel almaktadır. Bir diğer temel alınan nokta, hizmet kalitesinin yüksek olmadığı durumlarda tüketicilerin ileriye dönük olarak herhangi bir faaliyette bulunmadıklarıdır. Hizmet kalitesinin yüksek olması durumunda tüketiciler sadece yeniden satın alma faaliyetini göstermeyecek, aynı zamanda ürün ve hizmetleri başkalarına da tavsiye edeceklerdir (Boulding vd., 1993; Ruyter vd., 1998). Ruyter vd. (1998), Zeithaml ve diğerlerinden, hizmet kalitesi ve tüketicilerin daha fazla ödeme eğilimleri arasında pozitif bir ilişkinin olduğunu aktarmakta, tüketicilerin hizmet kalitesinin yüksek olması durumunda daha yüksek fiyat ödemeyi kabul ettiklerini ve fiyat yükseldiğinde bile markaya sadık kaldıklarını belirtmektedir.

Benzer yaklaşım sağlık hizmetlerinde de görülmektedir. Andaleeb (2001), hastanelerin hizmet kalitesi üzerine daha fazla eğildiklerini ve hasta tatmininin sağlanabilmesi için daha yüksek düzeyde kalitenin elde edilebilmesi için çalıştıklarını belirtmektedir. Bunun da ötesinde çalışma, hasta istek ve ihtiyaçlarının daha iyi tatmin edilmesi için kalite standartlarının hastalar tarafından belirlenebileceğini söylemektedir. Hizmet kalitesi arttıkça da tüketiciler daha yüksek düzeyde güven hissedecek, bu şekilde de sadece tedavi değil, aynı zamanda önleyici sağlık hizmetleri talep edebileceklerdir (Andaleeb, 2001).

\section{Tatmin}

Oliver (1980, s. 460)'a göre, tatmin kararlarının açılanmasında tüketicilerin performansa dönük beklentileri ile beklentilerin karşılanma dereceleri belirleyici rol oynamaktadır. Söz konusu bakış açısı çerçevesinde tüketiciler, satın alma öncesi hizmete dönük beklentileri ile hizmet alımı sonrası edindikleri deneyimin sonuçlarını karşılaştırmaktadır. Bu karşılaştırmanın sonucunun olumlu olması sonucunda oluşan duygu, tüketicinin tatmin düzeyini; beklentilerini karşılanmaması durumunda oluşan duygu ise tatminsizlik düzeyini belirlemektedir. Bu kapsamda, tatmin kararlarının oluşumu, temel anlamda hizmet kalitesinin değerlendirmesi ile paralellik gösterir.

Parasurman vd. (1994)'ne göre de, tüketicilerin tatmin düzeyi, beklenen kalite düzeyinin algılanan kalite düzeyi ile karşılaştırılması sonucu oluşmaktadır. Tüketici tarafından yapılan bu değerlendirmede, hizmetin kalitesini belirleyen fiyat ve uygunluk gibi birçok özellik, tüketici tarafından dikkate alınmaktadır.

Sağlık hizmetleri ile ilgili literatür de tatmin konusunu benzer yönleri ile ele almaktadır ${ }^{3}$. Linder-Pelz (1982, s. 580)'e göre, bireylerin sağlık hizmetlerinin farklı boyutlarının bireyler tarafindan olumlu değerlendirilmesi sonucu oluşan olumlu tutumdur. Linder-Pelz (1982), sağlık hizmetleri açısından tatmin oluşumu belirleyicilerinin, hastalığın meydana geliş sıklığı, sunulan hizmetin hasta açısından değeri, hastanın beklentileri, alınan sağlik hizmetinin diğer hizmet sağlayıcılardan elde edilen tecrübeler çerçevesinde kiyaslanması ve hastanın tedavi konusunda yetki vermek suretiyle tedavinin olası sonuçlarını kabullenmesi olmak üzere beş farklı sosyo-psikolojik faktör altında incelenebileceğini öne sürmüştür.

Sitzia ve Wood (1997) tarafından yapılan çalışmada, hasta tatminin belirleyicileri ve bileşenleri açısından kapsamlı bir değerlendirme sunularak, söz konusu etkenlerin belirli başlıklar altında sınıflandırılmasının yapılması amaçlanmıştır.

Bileşenler açısından hasta tatmininin oluşumu ele alındığında, hizmete erişilebilirlik, hekim-hasta ilişkisi, sağlık personelinin teknik kapasitesi ve hastaların bilgilendirilmesi hususlarının ön plana çıktığı görülmektedir. Sitzia ve Wood (1997), Ware vd. (1983)'nin yaklaşımına paralel şekilde hizmete erişilebilirlik bileşeni kapsamında; kolay ulaşım, hastane ortamı ve sağlık personelinin niteliğinin yanı sıra diğer personeller gibi fiziki özelliklerin, bekleme ve tedavi sürelerinin de tatmin oluşumunda hastalar tarafından değerlendirilen faktörler olduğunu belirtmektedir. Literatürde, söz konusu bileşenin hasta tatmini oluşumu açısından etkilerinin değerlendirildiği çalış-

3 Ancak, hasta tatmini ile tüketici tatmini arasında farklılıklar olduğu belirten çalışmaları da görmek literatürde mümkündür. Örneğin Verbeck (2004) tatmin duygusunun oluşumu açısından, tüketicilerin süreç odaklı bir değerlendirme yaptıklarını, hastaların ise daha çok sonuç odaklı değerlendirme yaptıklarını belirtmektedir. Bu kapsamda, hasta tatminin değerlendirilmesinin hem süreç hem de sonuç açısından ele alınması gerektiği belirtmektedir. 
malar görmek mümkündür. Örneğin, Mummalaneni ve Gopalakrishna (1997), sağlık hizmetlerinde hasta tatminin oluşumunda erişim-odaklı değișkenler kapsamında çalışma saatlerini, acil sağlık hizmetlerinin mevcudiyetini, hasta bekleme süresini, park yeri olanağ 1 ve tedavi hizmetlerinin uygunluğu faktörlerinin, hasta tatmininin oluşumu açısından etkili bileşenler olduğunu tespit etmişlerdir. Tehrani vd. (2011) ise Amerika Birleşik Devletleri'nde, 14.984 hasta kap- saminda, hastane hizmetlerinden elde edilen tatmin düzeylerinin oluşumunu, erişilebilirlik bileşeni açısından inceleyen bir araştırma yapmışlardır. Bu çalışmanın sonucunda hastaların bekleme ve tedavi sürelerinin, tatminin oluşumu açısından önemli bileşenler olduğu ve tatmin duygusunun hastalar tarafından değerlendirilmesinde bu öğelerin, yaş gruplarına göre farklılıklar gösterdiği ortaya konulmaktadır.

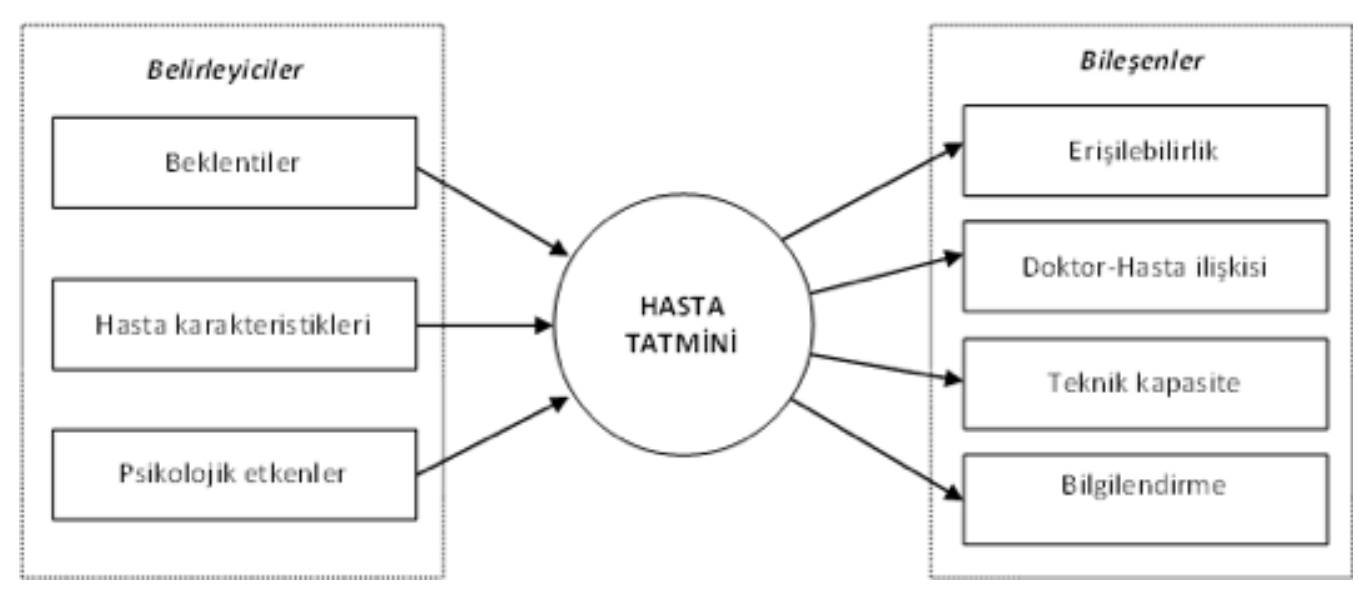

Şekil 1. Belirleyicileri ve Bileşenleri Açısından Hasta Tatmini

Hasta tatminin önemli bileşenlerinden birisi de hekim ve hasta arasındaki etkileşimden kaynaklanan faktörlerdir. Bu faktörler arasında en önemlileri ise iletişim ve empati olarak gösterilmektedir (Sitzia ve Wood, 1997). Blanchard vd. (1990) tarafindan yap1lan çalışmanın sonuçları da bu faktörün önemi konusunda kanıtlar sunmaktadır. Kanser hastaları üzerinde yapılan çalışmada, hastalara tedavi süreci ile ilgili bilginin yanı sıra duygusal olarak da destek verilen hasta grubunun, verilmeyen ${ }^{4}$ gruba göre tatmin düzeylerinin daha fazla olduğu gözlemlenmiştir. Benzer şekilde, Dufrene (2000) tarafından hasta tatmininin oluşumu konusunda yapılan çalışmada, hekim-hasta arasındaki ilişkiye ek olarak hemşire-hasta arasındaki iletişimin de nazik ve samimi bir şekilde olmasının, tatmin oluşumu açısından hastalar tarafından değerlendirildiğini ortaya koyulmuştur. Kim vd. (2004) ise hastalar ile hekimler arasındaki iletişimdeki empatinin, hastaların algıladıkları tatmin düzeyinin artıran önemli bir etken olduğunu gözlemlemiştir. Bu kap-

4 Sitzia ve Wood (1997) tarafından yapılan çalışmadan uyarlanmıștır. samda, sağlık personeli ile hasta arasındaki ilişkilerde içtenlik, samimiyet, nezaket ve empati ögelerinin, hasta tatmini konusunda önem taşıyan hususlar olarak belirtmek mümkün olmaktadır.

Hopkins (1990)'e göre, sağlık personeli tarafından sunulan hizmetin teknik yönünün hastalar tarafından tatmin bileşeni olarak değerlendirilmesi uygun değildir. ${ }^{5}$ Ancak, Sitzia ve Wood (1997), hastaların sağlık personelinin teknik kapasitesini değerlendirmesini, hasta tatmininin bileşenlerinden biri olarak belirtmekte ve birçok hastanın, edindikleri sağlık hizmeti ve hekimin tedavi ve ilaç bilgisinin yeterliliği yönündeki algılarını, tatmin konusundaki değerlendirmelerinde kullandığını ifade etmektedir.

Genel kabul görmüş hasta haklarına göre, hastaların bilgilendirilmesi ve eğitimi, hastaların temel haklarındandır. Bu haklar, birçok ülkede sağlık politikaları kapsamında güvence altına alınmıştır. Örneğin Türkiye'de Hasta Hakları Yönetmeliği’ne (Resmi Ga-

5 Aktaran: Sitzia ve Wood (1997, s. 1839) 
zete, Tarih: 01.08.1998; Sayı: 23420) göre, "Hasta; sağlik durumunu, kendisine uygulanacak tıbbi işlemleri, bunlarn faydaları ve muhtemel sakincalar, alternatif tıbbi müdahale usulleri, tedavinin kabul edilmemesi halinde ortaya çıkabilecek muhtemel sonuçları ve hastalı̆ğn seyri ve neticeleri konusunda sözlü veya yazılı olarak bilgi istemek hakkına sahiptir." Bu kapsamda, hastalara tedavi ile ilgili geniş kapsamlı bilgilerin verilmesi ile tatmin düzeylerini artış gösterdiği görülmektedir (Sitzia ve Wood, 1997; Vranceanu ve Ring, 2011). Benzer şekilde, Ovretveit (1996) de hastaların bilgilendirmesinin tatmin düzeylerinin yanı sıra alg1ladıkları kalite düzeylerinin oluşmasında önemli bir etken olduğunu ifade etmektedir.

Tatminin belirleyicileri, hastaların hastane tercihleri üzerinde etkili olduğu gibi, daha fazla ödeme eğilimleri üzerinde de etkili olmaktadır. Choi vd. (2004), müşteri tatmininin, hastaların işletmede kalması üzerinde etkili olduğunu söylemektedir. Cronin ve Taylor, (1992) de benzer bir şekilde, tatminin tüketicilerin yeniden satın alma eğilimlerini artırdığını ortaya koymaktadır. Anderson (1996) tüketici tatmini ile fiyat toleransı arasındaki ilişkiyi incelemiştir. Çalışmada fiyat toleransı, tüketicilerin ürün veya hizmeti değiştirmeden hemen önceki, ödemeyi kabul edecekleri en yüksek fiyat olarak tanımlanmaktadır. Anderson (1996) fiyat toleransına ilişkin olarak, bir tüketicinin belirli bir ürün veya hizmeti almak için ekonomik görebileceği ödeme miktarından daha fazla fiyat ödemeyi kabul edeceği miktar tanımından hareketle, yüksek tatmin düzeyinin, yüksek fiyat toleransına olanak tanıyacağını ifade etmektedir. Bolton ve Lemon (1999), tüketicilerin belirli bir hizmeti gelecekte satın almasının bağlı olduğu etkenlerden birinin de tatmin olduğunu söylemekte, yüksek fiyatların da yüksek tatmin düzeyi ile ilişkili olduğu sonucuna ulaşmaktadır. Tüketici tatmini ile daha fazla ödeme yapmaları arasındaki ilişkiyi inceleyen Homburg vd. (2005)'e göre, tüketiciler yüksek düzeyde tatmin sağladıklarında, söz konusu değişime ilişkin olarak yüksek düzeyde bir pozitif çıktı algılamakta, bunun sonucunda da daha yüksek düzeyde ödeme yapmayı göze almaktadırlar. Benzer mantıkla, düşük tatmin düzeyinde tüketiciler, ödedikleri düşük miktarda ücretin adil olduğunu düşünmektedir. Bunun nedeni, daha fazla ödeme eğiliminin tüketicilerin adil bir fiyat ödeme algıları ile ilgili olmasıdır.

\section{Güven}

Mooorman vd. (1993, s. 82) tarafından güven, bir değişim ortağına duyulan inanma isteği olarak tanımlanır. Benzer şekilde Morgan ve Hunt (1994) ise güven kavramını, bir tarafın, diğer tarafın güvenilirliği ve doğruluğuna inandığı zaman, yani bu kararın doğruluğu konusunda özgüven sahibi olduğu zaman hissettiği bir duygu olarak tanımlamaktadır. İşletmeler açısından tedarikçiler, aracılar ve satıcılar arasındaki ilişkide önemli bir unsur olan güvenin, işletme ile müşterisi arasındaki etkileşimin sürekliliği ve niteliği açısından da önemi büyüktür (Doney ve Cannon, 1997). Bu kapsamda, tüketici davranışı açısından güvenin, bir markanın tercih edilmesini sağlayan eşsiz bir üstünlük olarak değerlendirildiği görülmektedir (Chaudhuri ve Holbrook, 2001, s. 81). Hizmet sağlayııı işletmeler açısindan ise güven, tüketicilerin beklentileri ile ilişkilidir ve işletmenin vaatlerini yerine getirebilmesi ile doğru orantilıdır (Sirdeshmukh vd., 2002).

Sağllk hizmetlerine olan güven, literatürde kurumsal ve kişiler arası olmak üzere çok boyutlu bir şekilde ele alınmaktadır. Örneğin Mechanic (1998), güven kavramını daha çok hekim-hasta ilişkisi çerçevesinde değerlendirmektedir. Yazara göre, sağlık hizmetlerinde güven, kurum ile hasta arasındaki ilişkiden ziyade hasta ile hekim arasındaki ilişkinin bir çıktısıdır. Bu kapsamda hekim ile hasta arasındaki güvenin temeli direkt olarak tecrübe edinimi ile oluşurken; sağlık kurumları hakkında oluşan güven düzeyi, büyük oranda medyadan ya da diğer ikincil bilgi kaynaklarından elde edilmektedir. Mechanic (1998, s. 663-664), hekim ve hasta arasındaki ilişkide, hekimlerin yeteneği konusundaki hastanın beklentilerini, hekimlerin hasta sağlığına olan ilgisi, hekimlerin tedavi konusundaki etkinliği ve klinik hizmetlere sağlama imkânı, hekimlerin hastaların gizli bilgilerini saklı tutulması ve hekimlerin bilgi alma ve sağlama konusundaki açıklığı şeklinde boyutlarıyla açılklamaktadır.

Ancak, günümüz sağlık sistemini betimleyen yeni kamu yönetimi bakış açısı ve değişen pazar dinamikleri çerçevesinde, söz konusu geleneksel hekim-hasta ilişkisinin önemli derecede değişim gösterdiği de belirtmektedir (Riewpaiboon vd., 2005; Kraetschmer vd., 2004). Bu kapsamda, sağlık hizmetlerinde güvenin oluşumu, sağlık hizmeti sağlayıcısı olan kurum ve onun müşterisi ya da müşterilerine hizmet sunan hekim ile hastası arasındaki ilişkiler olmak üzere iki farklı yapıda açıklanmalıdır (Riewpaiboon vd., 2005, s. 1409). Bu paralelde, geleneksel hekim-hasta ilişkisinin (örn., Mainous vd., 2001; Pearson ve Raeke, 2000; Piette vd., 2005; Rehman vd., 2005; Thom vd., 2002) yanı sıra hastaların sağlık kuruluşuna duydukları güven düzeyinin sağlık hizmetlerindeki önemini ortaya koyan çalışmaları (örn., Lynn-McHale ve Deatrick, 2000, Mohseni ve Lindstrom, 2007; Rhodes ve Strain, 2000; Buchanan, 2000; Hall, vd., 2001) da 
literatürde görmek mümkündür. Bu kapsamda, sağlık hizmetlerinde güvenin çok boyutluluğuna ilişkin Hall vd. (2001) tarafindan yapılan sinıflandırmada, güven faktörü kișisel, kurumsal ve tüm sağlık sistemi açısından değerlendirilmiştir. Sinıflandırmanın esasında, sağlik hizmetinin sosyal bir sistem olarak görülmesi gerektiği ve hasta açısından güven duygusunun oluşumunda, hekim-hasta ilişkisinin yanı sıra kurumsal ve genel sağlık hizmeti politikalarının da etkili olduğu belirtilmektedir. Buna ek olarak Hall vd. (2001), bireysel güven oluşumu ile kurumsal düzeyde ve hatta tüm sağlık sistemi düzeyinde güven oluşumu arasında kuvvetli bir ilişki bulunduğunu da ifade etmektedirler. Hale etkisi (Halo effect) çerçevesinde tanımlanan bu etkinin kaynağ i iki yönlü olarak belirtilmektedir. Bu bakış açısı dâhilinde, hekime duyulan güven, onun mensubu olduğu sağlik kuruluşuna ve o sağlık kuruluşunun içinde bulunduğu sisteme olan güven duygusunu artırabilmektedir. Bunun tam tersi şekilde, kurumsal güvenin tesis edilmesi ile de hekimhasta arasındaki bireysel güven kazanılabilmektedir.

Sağlık hizmeti sektörü açısından güvenin makro ölçekteki etkisinin, hastaların sağllk kurulușu seçim kararlarında belirleyici etkisi bulunmaktadır (Gilson, 2003; Magee vd., 2003; van der Schee, 2007). Thiede (2005, s. 1454)'ye göre, özellikle toplumun sağllk hizmeti sağlayan kurumlara olan güveninin, pazarlama ve tüketici davranışı bakış açısı altında seçim seti (düşünme seti) ${ }^{6}$ çerçevesinde değerlendirilebilmesi mümkündür. Bu kapsamda, sağlık hizmetleri konusundaki bilgilendirme ile hastaların tedavi amaciyla düşündükleri sağlık kuruluşları alternatiflerini içeren seçim setinin nicel olarak artacağ ve bu set içerisinden tercih ettikleri sağlık kurumuna daha fazla güven duyacakları belirtilmektedir.

Tüm bunlar kapsamında ilgili literatür, hizmet sağlayıcı kurum ve hasta açısından incelendiğinde, sağlık hizmetlerinde güven konusunun çoğunlukla iki boyutlu bir yapıda ele alındığı görülmektedir. Örneğin Russell (2005), sağlık hizmetlerine olan güvenin, sunulan hizmetin kalitesi ile doğrudan ilişkili olduğunu ve güven kavramının, sağllk kuruluşunun klinik ve teknik kapasitesi ile çalıșanların hastalarla olan ilișkilerinin kalitesi (dinleme, kibarlık ve ilgi) olmak üzere iki boyutta açıklanması gerektiğini belirtmektedir. Benzer şekilde Mohseni ve Lindstrom (2007)'a göre

6 Seçim seti, karar alıcıların satın alma karar sürecinde seçim yapabilecekleri tüm alternatifleri içinde barındırır (Dölarslan, 2012). de, hasta güveni dikey ve yatay olmak üzere iki boyutlu bir yapı kapsamında açıklanabilir. Dikey yapı (kurumsal güven), sağllk hizmetlerinin sunulduğu sağlık kuruluşları ve sağlık sistemi ile hastalar arasındaki güveni temsil ederken; yatay yapı kapsamında, kişiler arası ilişkiler (hekimler ve sağlık personeli) söz konusu olmaktadır. Bu kapsamda, Hall vd. (2001)'nin bakış açısına paralel bir şekilde, kurumsal veya sisteme olan güven ile kişiler arası güven oluşumunun birbirlerini etkilediğini söylemek mümkün olmaktadır (Gilson, 2003; Mohseni ve Lindstrom, 2007; Roew ve Calnan, 2006; Hupcey ve Miller, 2006). Ancak, Roew ve Calnan (2006, s. 6)'a göre, özellikle kurumsal güvenin nasıl geliştirileceği konusunda çok az bilgi bulunmaktadır ve bu nedenle kurumsal güvenin ekonomik, politik ve sağlık açısından çıktılarının değerlendirildiği araştırmaların yapılması gerekmektedir.

Tüketicilerin hizmet sağlayıcı konusundaki tercihi, tüketicilerin hissettikleri güven ile direkt olarak ilgilidir. Temel olarak bu ilgi, güvenin belirsizliği düşürmesi ve böylece tüketicilerin algıladıkları risklerin düşmesiyle açıklanmaktadır (Weisberg vd. 2011). Bu şekilde tüketiciler hizmeti sağlayanlarla ilgili olarak, ileriye yönelik daha rahat ve güvenli tahminler yapabilecektir (Sirdeshmukh vd., 2002). Her ne kadar güven, sağlik kuruluşunun seçiminde önemli bir etken olarak öne çıksa da, daha fazla ödeme konusu sadece yukarıda ifade edilen durumlarla ilișkilendirilemez. Bu kapsamda güven aynı zamanda tüketicilerin daha fazla ödeme eğilimleri üzerinde önemli bir etken olarak da karşımıza çıkmaktadır (Harris ve Goode, 2004). Delgado-Ballester ve $\mathrm{Mu}-$ nuera-Aleman (2001), bunun temel nedeni olarak güvenin tüketicilerin belirli bir markaya yönelik sahip oldukları fiyat toleransını göstermektedirler. $\mathrm{Bu}$ durum öncelikli olarak güven duygusunun tüketici ve işletme arasında uzun dönemli olumlu ve güçlü ilișkilerin kurulması ile ilişkilendirilmektedir (Akbar ve Parvez, 2009). Değişime konu olan faaliyette bir taraf diğerine güven duyduğunda, pozitif bir davranışsal eğilim söz konusu olur. Tüketicilerin belirli bir düzeyin üstünde ödeme yapmayı kabul etmeleri ise sadece pozitif bir sonuca ulaşılması ile değil; ayrıca, oluşan güven ve olumlu uzun dönemli ilișkiler sayesinde söz konusu pozitif sonucun gelecekte de devam edeceğine olan inanca dayanır (Akbar ve Parvez, 2009). Güven duygusunun uzun dönemde bağll11kla sonuçlandığını gösteren çalışmalar dikkate alındığında (örn., Alhabeeb, 2007), güvenin tüketicilerin daha fazla ödeme eğilimlerini artıran bir etken olduğunu söylemek mümkündür. 


\section{Hipotezler ve Araştırma Modelinin Geliştirmesi}

Sağllk hizmetlerinden yararlanan hastaların, tüketici davranışı perspektifinde DÖE eğilimlerinin oluşumunda etkili olan değişkenlerin, belirleyicileri ve etkileri açısından birbirlerine benzer kavramlar üzerinde temellendikleri görülmektedir. Bununla beraber, hizmet kalitesi, tatmin ve güven değişkenleri arasındaki ilişkilerin, gerek sağlık hizmetleri gerekse de hizmet pazarlaması literatüründe desteklendiğini ve bunun yanı sıra kamu ve devlet hastanesi tercihinin hastaların davranışsal niyetlerinin oluşumunda belirleyici etkisi bulunduğunu görmek mümkündür. Bu kapsamda, çalışma çerçevesinde öne sürülen hipotezler, doğrudan ilişkiler ve düzenleyici etkiler olmak üzere iki kısımda sunulmaktadır.

\section{Doğrudan Etkiler}

Oliver (1980) tarafından yapılan kavramsal çerçevede, beklenen ve algilanan kalite arasindaki performans düzeyi olarak tanımlanan tatmin duygusunu, tüketicilerin algıladıkları kalite düzeyinden ayrı bir şekilde değerlendirmek mümkün değildir. Hizmet değerlendirme sürecini ele alan çalışmalarda da, algılanan kalite ve tatmin arasındaki ilişki, yoğun bir şekilde değerlendirilmiştir (örn., Cronin ve Taylor, 1992; Gotlieb vd., 1994; Ibannez vd., 2006). Bu çalışmalardan ortaya çıkan sonuçlar, tüketicilerin algilanan hizmet kalitesi ile tatmin düzeyleri arasında, doğrudan bir ilişki bulunduğu yönündedir. Bu bağlamda, sağlık hizmetleri konusunda yapılan çalışmalarda da, kuruma yönelik algılanan kalite düzeyi ile hasta tatmini arasındaki ilişkiyi destekler yönde kanıtların bulunduğu görülmektedir. Örneğin, Gotlieb vd. (1994)'ne göre, hastaların kurumsal açıdan yaptıkları kalite değerlendirmelerinin sonuçlarının, bireysel tatmin düzeyinin oluşumu üzerinde olumlu bir etkisi bulunmaktadır. Küçükarslan ve Nadkarni (2008) tarafından yapılan çalışmada ise hastaların hizmet aldıkları hastanelere ilişkin beklentilerinin karşılanma durumunun, algılanan kalitenin belirleyicisi olduğu ve bu şekilde tatmin düzeyinin oluşmasinda, algılanan kalite düzeyinin doğrudan belirleyici etki gösterdiği tespit edilmiştir. Benzer şekilde, sağlık hizmetlerindeki kalite algısını, kurumsal ve hekimhasta ilişkileri açısından beraberce değerlendiren çalışmalarda (örn., Andaleeb, 2001; Bowers vd., 1994; Choi vd., 2004; Deniz ve Hobikoğlu, 2011; Dursun ve Çerçi, 2004; Reidenbach, 1990; Tanrıverdi ve Erdem, 2010; Özen vd., 2011; Varinli ve Çakır, 2004) da, has- taların algıladıkları kalite düzeyleri ile tatmin düzeyleri arasında ilişkinin doğrudan ve olumlu yönde olduğu ortaya konulmaktadır. Bu çerçevede, aşağıdaki hipotez oluşturulmuştur.

H1: Hastaların algılanan kalite düzeyi, tatmin düzeylerini olumlu yönde etkilemektedir.

Algılanan kalite ile güven düzeyi arasındaki ilişki açısından literatür incelendiğinde, tüketicilerin alg1ladıkları kalite düzeyinin, hizmet sağlayan işletmeye olan güven düzeylerini artırarak, desteklediği görülmektedir. Chiou ve Droge (2006, s. 615)'ye göre sadakat oluşumunda güven etkili faktörlerdendir ve tüketici güveninin oluşması açısından da hizmet kalitesi belirleyici bir unsur olarak kendini göstermektedir. Benzer şekilde Gounaris (2005) tarafindan yapılan çalışmada da, kalitenin güven düzeyi üzerindeki doğrudan etkisi tespit edilmiştir. Kalite boyutları açısından, güven düzeyinin oluşumu ele alan çalışmalar da bulunmaktadır. Örneğin, Sharma ve Patterson (1999) ve Eisingerich ve Bell (2008) tarafindan yapılan çalışmalarda, kalitenin teknik ve fonksiyonel boyutlarının, güven düzeyinin oluşumu açısından doğrudan etkili faktörler olduğu tespit edilmiştir. $\mathrm{Bu}$ açıdan, sağlık hizmetlerinde algılanan kalite düzeyi, kurumsal güvenin oluşumu açısından da etkili bir faktördür. Mohsani ve Lindstrom (2007)'a göre, gerek hekim-hasta arasındaki gerekse de hasta-kurum arasındaki ilişkinin kalitesine dönük hasta algısının yüksek olması, kişiler arası ya da kurumsal güvenin oluşumu açısından belirleyici nitelik taşımaktadır. Bu kapsamda aşağıdaki hipotezi oluşturmak olanaklı hale gelmektedir.

H2: Hastaların algılanan kalite düzeyi, kurumsal güven düzeylerini olumlu yönde etkilemektedir.

Özellikle hizmet pazarlaması perspektifinde, müşterilerin hizmet sağlayıcı işletmenin kalitesi açısından yaptıkları değerlendirme, davranışsal niyetleri ve buna bağlı olarak sadakat davranışlarının oluşumu açısından yoğun bir şekilde değerlendirilmiştir. Ancak, literatürde, algılanan hizmet kalitesinin, davranışsal niyet ve buna bağlı sadakat davranışları oluşumundaki doğrudan etkisinin varlığı tartışmalı bir konudur. Bazı çalışmalarda hizmet kalitesinin salt olarak, davranışsal niyeti açıklama konusunda doğrudan etkili bir faktör olmadığ 1 belirtilmektedir (örn., Hutchinson vd., 2009; Cronin vd., 1997). Ancak, Cronin vd. (2000)'e göre hizmet kalitesi, dav- 
ranışsal niyetin oluşumu açısından doğrudan etkili bir faktör olmakla beraber; davranıșsal niyetin oluşmasında değer ve tatmin üzerinden dolaylı etkisi de bulunmaktadır. Benzer şekilde Brady vd. (2005) tarafından yapılan çalışmada da hizmet kalitesinin davranışsal niyet üzerindeki doğrudan ve dolaylı etkileri, farklı ülke örneklemlerinde test edilmek suretiyle tespit edilmiştir. Sağlık hizmetleri sektöründe yapılan çalışmalarda ise hastaların algılanan kalite düzeyinin davranışsal niyetin oluşumu açısından etkili olduğunu destekleyen çalışmalar bulunmaktadır. Örneğin Choi vd. (2004), kalite, değer ve tatminin davranışsal niyetin oluşumu açısından etkilerini model kapsamında değerlendirmişlerdir. Hastaneler kapsamında yapılan bu çalışmanın sonucunda, hizmet kalitesinin davranışsal niyet üzerindeki doğrudan etkisinin yanı sıra, değer ve tatmin üzerinden de dolaylı etkisi bulunduğu tespit edilmiştir. Davranışsal niyet ve sadakat davranışlarının oluşumu açısından hastaların DÖE’nin değerlendirildiği Baji vd. (2012) tarafından yapılan çalışmada ise hastaların algılanan kalite düzeyleri ile ödeme eğilimleri arasında olumlu bir ilişki bulunduğu belirtilmektedir. Tüm bunlar kapsamında, algılanan kalite düzeyi ile DÖE arasındaki ilişkiyi betimleyen hipotez aşağıda sunulmaktadır.

H3: Hastaların algılanan kalite düzeyi, daha fazla ödeme eğilimlerini olumlu yönde etkilemektedir.

Literatürde, güven duygusunun oluşumu açısından tatmin üzerinden yapılan değerlendirmeler, iki değişken arasında doğrudan ilişkinin varlığını desteklemektedir. Örneğin Garbarino ve Jhonson (1999), güvenin, sadakat ve davranışsal niyet oluşumu açısından önemli bir faktör olduğunu ve bununla beraber tatmin düzeyi ile güven duygusu arasında doğrudan ilişki olduğunu belirtmektedir. Johnson ve Grayson (2005) ise müşteri açısından güveni bilişsel (işletmeye olan güven) ve duygusal (kişisel özgüven) olmak üzere iki boyutta ele alarak, tatmin düzeyi ile güven boyutları arasındaki ilişkiyi test etmişlerdir. Bu çalışmanın sonucunda, algılanan tatmin düzeyinin bilişsel güven üzerinde etkili olduğu ve bilişsel güvenin de duygusal güvenin belirleyicisi olduğu tespit edilmiştir. Benzer şekilde, Goold ve Klipp (2002) ise hastaların beklenti ve algılarının sonucunda oluşan tatmin değerlendirmeleri ile hastaneye olan güvenin oluşumunun ilişkili olduğunu belirtmektedir.
Oliver (1999, s. 33)'a göre, tatmin ile sadakat arasında çok kuvvetli bir ilişki bulunmaktadır. Buna ek olarak, geçmiş çalışmalardan (örn., Reichheld ve Sasser, 1990; Srinivasan vd., 2002) elde edilen sonuçlar, sadık müşterilerin sadık olmayanlara oranla daha düşük fiyat elastikiyetine sahip olduklarını göstermektedir. Bu kapsamda, hizmet pazarlaması literatüründe, tatminin davranışsal niyet ve sadakat üzerindeki etkisi, DÖE’nin de içinde bulunduğu çeşitli sadakat davranışları çerçevesinde değerlendirilmektedir (Srinivasan vd., 2002). Örneğin, Anderson (1996) tarafından yapilan çalı̧̧ma, müşterilerin tatmin düzeyi ile DÖE ve fiyata olan tolerans düzeyleri arasındaki ilişkinin, tatmin düzeyi ve fiyat toleransı açısından ters yönlü olduğunu; tatmin olan müşterilerin, daha az fiyat toleransına sahip olmaları nedeniyle DÖE sergilediklerini tespit etmiştir. Benzer şekilde, Homburg vd. (2005) tarafından yapılan çalışmadan elde edilen sonuçlar da, tatmin düzeyi ile ödeme eğilimi arasındaki ilişkinin olumlu olduğunu destekler yöndedir. Bu kapsamda, hastaların tatmin düzeyinin kurumsal güveninin oluşumuna ek olarak, ödeme eğiliminin artması konusunda etkileri açısından sunulan teorik yapı çerçevesinde, aşağıdaki hipotezleri oluşturmak mümkün olmaktadır.

H4: Hastaların tatmin düzeyi, kurumsal güven düzeylerini olumlu yönde etkilemektedir.

H5: Hastaların tatmin düzeyi, daha fazla ödeme eğilimlerini olumlu yönde etkilemektedir.

Sirdeshmukh vd. (2002)'ne göre çok boyutlu bir yapı sergileyen sadakat davranışları ile güven arasında doğrudan bir ilişki söz konusudur. Algılanan risk düzeyinin düşmesi ile oluşan işletmeye duyulan güven düzeyi, tüketicinin gelecekteki satın alma davranışlarında, işletmenin tercih edilmesi açısından olumlu yönde etkide bulunmaktadır. Caceres ve Paparoidamis (2007), hizmet kalitesinin algilanan teknik ve fonksiyonel yönü ile sadakat davranışının oluşumu arasındaki ilişkide, güven düzeyinin tam aracılık etkisi bulunduğunu tespit etmişlerdir. Benzer şekilde Harris ve Goode (2004)'ye göre, hizmet değerlendirme süreci çerçevesinde sadakatin oluşmasında, müşteri güven düzeyi merkezi bir rol üstlenmektedir. Chiou ve Droge (2006) ve Ibanez vd. (2006) tarafin- 
dan yapılan çalışmalardan elde edilen bulgular da, güven düzeyinin tatminin yanı sıra davranışsal sadakat davranışları üzerinde dolaylı ve doğrudan etkisi bulunduğu ortaya koyar niteliktedir. Hasta açısından güven düzeyi ve ödeme eğilimi arasındaki ilişkiyi değerlendiren çalışmalar da, gerek hekim ile hasta arasındaki ilişkide (örn., Kao vd., 1998), gerekse de hasta ile hizmet sağlayan kurum arasındaki ilişkideki (örn., Russel, 2005) hasta güven düzeyinin, DÖE üzerinde olumlu yönde etkiler gösterdiğine dair kanıtlar sunmaktadır. Bu kapsamda, aşağıdaki hipotezi oluşturmak olanaklı hale gelmektedir.

H6: Hastaların kurumsal güven düzeyi, daha fazla ödeme eğilimlerini olumlu yönde etkilemektedir.

\section{Hastaların Hastane Tercihlerinin Düzenleyici Etkisi}

Hastaların sağlık hizmetlerine erişiminde, sağlık hizmetini sunan kuruluşun yapısı önem taşımaktadır. Sağlık hizmeti harcamalarının farklılaşmasında, hizmeti sunan kuruluşun niteliğine ek olarak, genel sağlık sisteminin yapısı da belirleyici rol oynamaktadır (Siskou vd., 2008, s. 290-292). Ülkelerin sağlık sistemlerinin daha etkili bir şekilde yürütülmesine yardımcı olan özel sağlık kurumları, sunulan sağlık hizmetinin kalite ve standartlarını iyileştirmesinin yanı sıra, sağlık hizmetlerine olan talebin uzun dönemli bir şekilde karşılanabilmesine yardımcı olmaktadır (Bartlett ve Philips, 1996; Tountas vd., 2005). Sunulan sağlık hizmetini özel veya kamu sahipliğindeki kurumlar açısından değerlendiren çalışmalarda da, hastaların güven (örn., Russel, 2005), kalite (örn., Andeleb, 2000; Deniz ve Hobikoğlu, 2011), tatmin (örn., Andeleb, 2001) ve ödeme eğilimi (örn., Baji vd., 2012) düzeylerinin farklılaştığı ortaya konulmaktadır. Hâlihazırda, Türkiyede uygulanan sağlık hizmetlerinin ücretlendirilme politikası kapsamında, hastanelerin kalite düzeyleri ile ilişkilendirilen tedavi ücretleri, kaliteye bağlı oluşturulan bir finans sisteminin varlığını destekler niteliktedir. Bu nedenle, Raju ve Lonial (2002)'nin bakış açısına paralel olarak, sağlık hizmetlerinin finansal performans düzeyinin oluşumunda, hizmet kalitesinin ve sürecinin çıkt1larının, pazar odaklı bir yapıda değerlendirmesi ka- çınılmaz olmaktadır. Tüm bunlar kapsamında, hastaların DÖE’nin oluşumunu değerlendiren sürecin bütünsel olarak, kamu ve özel hastaneler kapsamında değerlendirilmesinin de gerekli olduğu düşünülmektedir. Buna ilişkin oluşturulan genel modele ve model kapsamında sunulan diğer düzenleyici etkilere ilişkin hipotezler aşağıda belirtilmektedir.

H7: Devlet ve özel hastane tercihinin, önerilen daha fazla ödeme eğilimi oluşumu modelindeki ilişkiler üzerinde düzenleyicilik etkisi bulunmaktadir.

- H7: Devlet ve özel hastane tercihinin, algllanan hizmet kalitesi ve hasta tatmin düzeyi arasındaki ilişkide düzenleyicilik etkisi bulunmaktadır.

- H7 $7_{b}$ Devlet ve özel hastane tercihinin, algilanan hizmet kalitesi ve kurumsal güven arasındaki ilişkide düzenleyicilik etkisi bulunmaktadir.

- H7 : Devlet ve özel hastane tercihinin, algilanan hizmet kalitesi ve daha fazla ödeme eğilimi arasındaki ilişkide düzenleyicilik etkisi bulunmaktadır.

- H7 ${ }_{d}$ : Devlet ve özel hastane tercihinin, hasta tatmin düzeyi ve hasta kurumsal güven düzeyi arasındaki ilişkide düzenleyicilik etkisi bulunmaktadır.

- H7 : Devlet ve özel hastane tercihinin, hasta tatmin düzeyi ve daha fazla ödeme eğilimi arasındaki ilişkide düzenleyicilik etkisi bulunmaktadır.

- H7 f Devlet ve özel hastane tercihinin, kurumsal güven düzeyi ve daha fazla ödeme eğilimi arasındaki ilişkide düzenleyicilik etkisi bulunmaktadır.

Bu bağlamda, değişkenler arasındaki doğrudan etkileri ve söz konusu ilişkiler kapsamında hastane seçiminin düzenleyici etkilerini içeren araştırma modelinin gösterimi ise Şekil 1 kapsamında sunulmaktadır. 


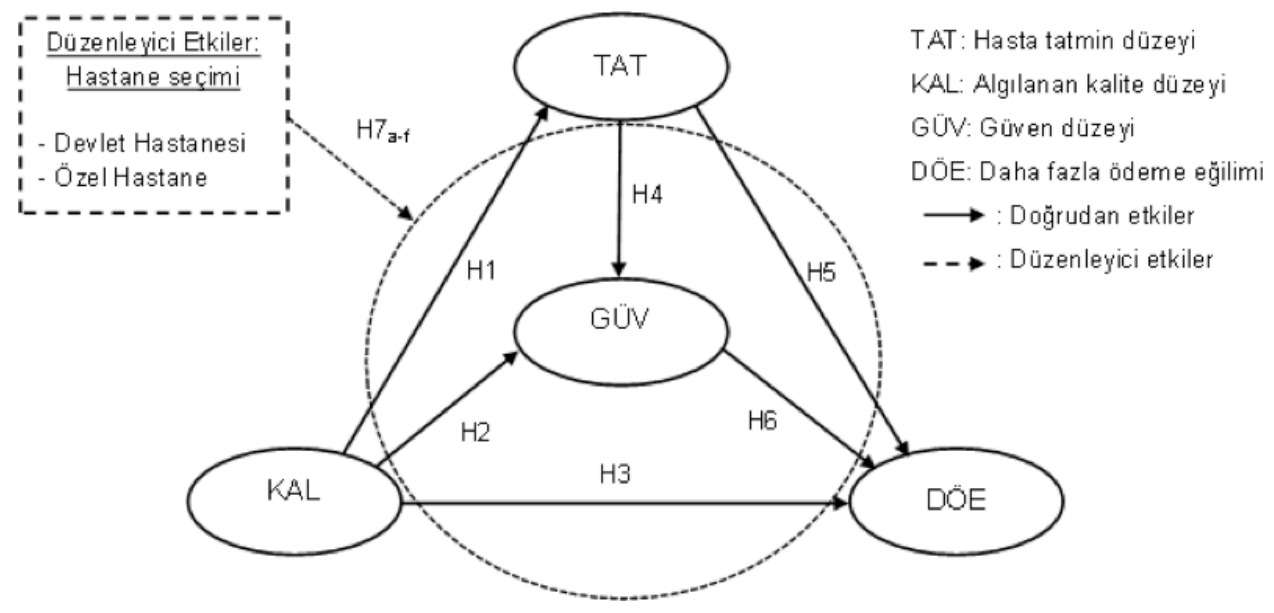

Şekil 1. Araştırma Modeli

\section{Uygulama: Araştırma Modelinin Test Edilmesi}

\section{Örneklem Seçimi ve Verilerin Analiz Yöntemi}

Kolayda örnekleme yöntemi kullanılan bu çalışmada, araştırma evreni olarak Çankırı'da ikamet eden hastalar seçilmiştir. İl merkezinde yalnızca bir kamu ve bir özel hastanenin bulunması nedeniyle, araştırmaya konu olan modelin test edilmesi açısından Çankırı ilinin uygun olduğu düşünülmüştür. Bir başka ifadeyle, kamu ve özel hastane tercihi açısından hastaların seçim setinin sınırlı olduğu bu anakütle, kıyaslama yapabilmek açısından elverişli bir özelliktedir. Bu kapsamda, araştırma modelinin değerlendirilmesinde, veri toplama aracı olarak anket yöntemi uygulanmış; yalnızca SGK'na mensup olan hastalara uygulanan 450 anketin, eksik veya yanlış doldurulmaları nedeniyle 437 adedi analize alınmıştır.

Çalışmaya temel olan araştırma modeli, Yapısal Eşitlik Modellemesi (YEM) ile test edilmiştir. YEM analizlerinde örneklem büyüklüğü ile ilgili olarak, normal dağılmış bir veri seti için genel olarak 100 say1sının asgari, 200 sayısının da kabul edilebilir sınırlar içinde olduğu belirtilmekle beraber; verilerin normal dağıldığı ve değişkenler arasındaki ilişkilerin göreceli olarak yüksek olduğu modellerde, gözlenen değişken sayısının on katı civarında bir örneklem sayısı yeterli olarak kabul edilmektedir (Şimşek, 2007, s. 55). Bu kapsamda, uygulamaya konu olan 437 kişilik örneklem sayısının yeterli olduğu söylenebilir.

Araştırma sürecinde verilerin analizi, üç aşamalı yaklaşım benimsenerek gerçekleştirilmiştir. Bu kapsamda öncelikle, değişkenlerin tek boyutluluğunu değerlendirmek amacıyla açıklayıcı faktör analizi (AFA) yapılmıştır. Bu aşamadan sonra, ölçme modelini test etmek amacıyla modeli oluşturan değişkenlere doğrulayıcı faktör analizi (DFA) uygulanmıştır. Daha sonra DFA ile test edilen ölçme modelinin güvenilirlik ve geçerlilikleri testleri yapılarak, yapısal eşitlik modellemesi ile model kapsamında sunulan doğrudan ve düzenleyici etkiler test edilmiştir. Analizlerde SPSS 20.0 ve LISREL 8.51 istatistik paket programları kullanılmıştır.

\section{Ölçekler ve Anket Formunun Oluşturulması}

İki bölümde yapılandırılan anket formunun ilk bölümünde, yanıtlayıcıların cinsiyet, aylık gelir, yaş, eğitim durumu ve medeni durumuna ek olarak, sağllk hizmeti konusunda tercih ettikleri hastaneler sorulmuştur. İkinci bölüm kapsamında ise kurumsal güven, tatmin, algilanan kalite ve daha fazla ödeme eğilimi (DÖE) değişkenlerine ilişkin sorular, daha önceki çalışmalarda geçerliliği ve güvenilirliği test edilmiş ölçekler kapsamında oluşturularak, yanıtlayıcılara sunulmuştur (Tablo 2). Algılanan kalite (KAL) ve tatmin (TAT) ile ilgili sunulan ölçekler, Cronin vd. (2000) tarafından yapılan çalışmadan alınmıştır. Gü- 
ven değişkeni (GÜV) için Zhang ve Bloomer (2008) tarafından uygulaması yapılan beş sorudan oluşan ölçek kullanılmıştır. Daha fazla ödem eğilimini (DÖE) ölçek amacıyla Baker ve Crompton (2000) tarafından yapılan çalışmadan alınan ölçek kullanılmıştır. KAL dışındaki tüm ölçekler beşli Likert ölçeği kapsamında yanıtlayıcılara sunulurken, algılanan kalite değişkeni yine beşli aralıkta semantik farklılık ölçeği kullanılmak suretiyle anket formunda yer almıştır.

\section{Analiz ve Bulgular}

\section{Örneklem Özellikleri ve Tanımlayıcı İstatistikler}

Araştırmaya konu olan örneklemin özelliklerine ilişkin veriler Tablo 1'de sunulmaktadır. İlgili tablo incelendiğinde, yanıtlayıcıların orta gelir düzeyinde ve çoğunlukla 26 ila 45 yaş aralı̆̆ında oldukları tespit edilmiştir. Bunun yanı sıra, tercih ettikleri hastanenin belirlenmesi açısından anket formlarının karşılaştırılabilir örneklem sayılarına ulaştıkları da görülmektedir.

Tablo 1. Örneklem Özellikleri

\begin{tabular}{|c|c|c|c|c|c|}
\hline & $\mathrm{n}(437)$ & $\%$ & & $\mathrm{n}(437)$ & $\%$ \\
\hline Cinsiyet & & & Eğitim Durumu & & \\
\hline Kadın & 189 & 43.2 & İlköğretim & 90 & 20.6 \\
\hline Erkek & 248 & 56.8 & Lise & 163 & 37.3 \\
\hline Aylık Gelir (TL) & & & Ön lisans & 69 & 15.8 \\
\hline$>750$ & 46 & 10.5 & Lisans & 101 & 23.1 \\
\hline $751-1500$ & 141 & 32.3 & Lisansüstü & 14 & 3.2 \\
\hline $1501-2250$ & 136 & 31.1 & Medeni Durum & & \\
\hline $2251-3000$ & 70 & 16.0 & Evli & 249 & 56.98 \\
\hline $3001>$ & 44 & 10.1 & Bekâr & 188 & 43.02 \\
\hline Yaş & & & Tercih edilen hastane & & \\
\hline$>26$ & 100 & 22.9 & Devlet & 264 & 60.4 \\
\hline $26-35$ & 175 & 40 & Özel & 173 & 39.6 \\
\hline $36-45$ & 100 & 22.9 & & & \\
\hline $46-55$ & 44 & 10.1 & & & \\
\hline $55>$ & 18 & 4.1 & & & \\
\hline
\end{tabular}

Değişkenlerin ortalaması, standart sapması, basıklık ve çarpıklık değerleri ise Tablo 2'de sunulmuştur. YEM ile araştırma modelinin test edildiği bu çalışmada, tahmin yöntemi olarak Maksimum Olasılık Tahmin Yöntemi (Maximum Likelihood Estimation) kullanılmıştır. Bu yöntemin gereği olarak, ölçme modelini oluşturan örtük değişkenlere (yapılar) ait gözlenen değişkenlerin basıklık ve çarpıklık değerleri kapsamında çok değișkenli normallik özelliklerinin test edilmesi gerekmektedir. Bu kapsamda, değişkenlerin çarpıklık değerinin 2'den, basıklık değerinin de 7'den düşük olması önerilmektedir (Hong vd., 2003, s. 642; West, vd., 1995). Bu çalışmada test edilen modellerin gözlenen değişkenlerinin çarpıklık değerlerinin -0.900 ile 0.427 arasında, basıklık değerlerinin ise - 1.826 ile 0.602 arasinda olduğunun görülmesi nedeniyle, çok değişkenli normallik özelliğinin sağlanmış olduğu söylenebilir. 


\section{Tablo 2. Tanımlayıcı İstatistikler}

\begin{tabular}{|c|c|c|c|c|}
\hline Ölçekler (Gözlenen değişkenler) & Ortalama & $\begin{array}{l}\text { Standart } \\
\text { Sapma }\end{array}$ & Basıklık & Çarpıklık \\
\hline Güvl: Bu hastaneye güvenebileceğimi hissediyorum. & 3.447 & 1.027 & -1.826 & 0.427 \\
\hline $\begin{array}{l}\text { Güv2: Bu hastanenin verdiği sözlerde gerçekten samimi olduğunu } \\
\text { düşünüyorum. }\end{array}$ & 3.339 & 0.981 & 0.117 & -0.851 \\
\hline $\begin{array}{l}\text { Güv3: Bu hastanenin bana karş1 dürüst ve doğru olduğunu } \\
\text { düşünüyorum. }\end{array}$ & 3.449 & 0.939 & -0.106 & -0.589 \\
\hline $\begin{array}{l}\text { Güv4: Bu hastanenin bana adil ve doğru şekilde davrandığını } \\
\text { düşünüyorum. }\end{array}$ & 3.350 & 1.013 & 0.101 & -0.720 \\
\hline $\begin{array}{l}\text { Güv5: Onların yardımına ihtiyacım olduğunda bu hastanenin bana } \\
\text { yardım edebileceğini hissediyorum }\end{array}$ & 3.675 & 0.967 & -0.234 & -0.558 \\
\hline $\begin{array}{l}\text { Tat1: Bu hastaneden hizmet alma kararımın akillıca olduğunu } \\
\text { düşünüyorum. }\end{array}$ & 3.346 & 1.030 & 0.602 & -0.900 \\
\hline $\begin{array}{l}\text { Tat2: Bu hastaneden hizmet almakla doğru bir iş yaptığımı } \\
\text { düşünüyorum. }\end{array}$ & 3.381 & 1.004 & -0.085 & -0.655 \\
\hline $\begin{array}{l}\text { Tat3: Bu hastanenin sağllk hizmeti almak için gerekli olduğunu } \\
\text { düşünüyorum. }\end{array}$ & 3.581 & 1.014 & -0.150 & -0.614 \\
\hline $\begin{array}{l}\text { Döel: Fiyatları bir miktar artsa bile, bu hastaneden hizmet almaya } \\
\text { devam edeceğim. }\end{array}$ & 2.842 & 1.238 & 0.304 & -0.812 \\
\hline $\begin{array}{l}\text { Döe2: Diğerine göre bu hastaneye daha yüksek fiyat ödemeye } \\
\text { razıyım. }\end{array}$ & 2.468 & 1.202 & -1.023 & -0.003 \\
\hline $\begin{array}{l}\text { Kall: X Hastanesinin hizmet kalitesi: } \\
\qquad \text { "Yetersizdir" } 1 \ldots 2 . .3 \ldots 4 \ldots 5 \text { "Mükemmeldir" }\end{array}$ & 3.163 & 1.030 & -0.970 & 0.347 \\
\hline $\begin{array}{l}\text { Kal2: X Hastanesinin hizmet kalitesi: } \\
\qquad \text { "Düşük niteliklidir " } 1 \ldots 2 \ldots 3 \ldots 4 \ldots 5 \text { "Üstün niteliklidir" }\end{array}$ & 3.195 & 1.037 & -0.360 & -0.381 \\
\hline $\begin{array}{l}\text { Kal3: X Hastanesinin hizmet kalitesi: } \\
\text { "Düşük standartlardadır " 1..2 ...3 ...4 ...5 "Yüksek standartlardadır" }\end{array}$ & 3.216 & 1.022 & -0.328 & -0.211 \\
\hline
\end{tabular}

\section{Açıklayıcı Faktör Analizi}

AFA kapsamında yapılan analiz, Temel Bileşenler (Principal Compenents) yöntemine dayanılarak, varimax rotasyonlu olarak uygulanmış ve örneklem yeterliliğini değerlendirmek amacıyla Kaiser-MeyerOlkin (KMO) testinde sınır değer 0.50 olarak kabul edilmiştir (Tablo 3). Analiz sonucunda, değişkenler arasında yeterli ilişki bulunup bulunmadığını gösteren Bartlett küresellik testi sonuçlarına göre de değişkenler arasında faktör analizi yapmaya yeterli düzeyde bir ilişki bulunduğu $(\mathrm{p}<0.05)$ görülmüştür (Sipahi vd., 2006, s. 80-81). Tek boyutlu olarak GÜV değişkeninin \% 66.350, TAT değişkeninin \% 78.554, KAL değişkenin \% 84.083 ve DÖE değişkenin \%
83.567 oranında açıklanan varyans değerlerine sahip oldukları ve bu değerlerin de \% 50'den büyük olduğu da saptanmıştır. Bu sonuçlara göre faktör analizine konu olan değişkenlerin tümünün, özdeğeri 1 ya da 1'den büyük olarak, tek bir boyutta açıklandığı tespit edilmiştir.

$\mathrm{Bu}$ aşamadan sonra, elde edilen faktör yapılarının iç tutarlılıklarının belirlenmesi amacıyla Cronbach's Alpha ( $\alpha$ ) analizi yapılmıştır. Tablo 3 incelendiğinde, elde edilen değerlerin sınır değer olarak önerilen 0.70 'den oldukça yüksek olduğu görülmektedir. Bu nedenlerle değişkenlerin DFA aşamasına alınması uygun görülmüştür. 
Hizmet Kalitesi, Tatmin ve Güvenin Daha Fazla Ödeme Eğilimi Üzerindeki Etkileri

Tablo 3. Açıklayıcı Faktör Analizi Sonuçları

\begin{tabular}{|c|c|c|c|c|c|}
\hline & $\begin{array}{l}\text { Boyut } \\
\text { sayis1 }\end{array}$ & Özdeğer & $\begin{array}{l}\text { Açıklanan } \\
\text { Varyans Oranı }\end{array}$ & $\begin{array}{l}\text { Kümülatif } \\
\text { Varyans Oranı }\end{array}$ & Cronbach's Alpha $(\alpha)$ \\
\hline \multirow{10}{*}{ GÜV } & 1 & 3.317 & 66.350 & 66.350 & \multirow{11}{*}{0.872} \\
\hline & 2 & 0,555 & 11.105 & 77.455 & \\
\hline & 3 & 0.494 & 9.884 & 87.339 & \\
\hline & 4 & 0.346 & 6.922 & 94.261 & \\
\hline & 5 & 0.287 & 5.739 & 100.000 & \\
\hline & KMO & & & $: 0.859$ & \\
\hline & \multicolumn{4}{|c|}{ Bartlett küresellik testi sonuçları } & \\
\hline & & \multicolumn{2}{|c|}{ Ki-kare $(\chi 2)$} & $: 1041.879$ & \\
\hline & & \multicolumn{2}{|c|}{ Serbestlik derecesi (sd) } & $: 10$ & \\
\hline & & \multicolumn{2}{|c|}{ Anlamlılık düzeyi (p) } & $: 0.000$ & \\
\hline \multirow{8}{*}{ TAT } & 1 & 2.357 & 78.554 & 78.554 & \\
\hline & 2 & 0.459 & 15.291 & 93.845 & \multirow[t]{2}{*}{0.862} \\
\hline & 3 & 0.185 & 6.155 & 100.000 & \\
\hline & \multicolumn{3}{|l|}{ KMO } & $: 0.684$ & \\
\hline & \multicolumn{4}{|c|}{ Bartlett küresellik testi sonuçları } & \\
\hline & \multicolumn{3}{|c|}{ Ki-kare $\left(\chi^{2}\right)$} & : 697.994 & \\
\hline & \multicolumn{3}{|c|}{ Serbestlik derecesi (sd) } & $: 3$ & \\
\hline & \multicolumn{3}{|c|}{ Anlamlılık düzeyi (p) } & $: 0.000$ & \\
\hline \multirow{8}{*}{ DÖE } & 1 & 1.671 & 83.567 & 83.567 & \multirow{2}{*}{0.803} \\
\hline & 2 & 0.329 & 16.433 & 100.000 & \\
\hline & KMO & & & $: 0.500$ & \\
\hline & \multicolumn{4}{|c|}{ Bartlett küresellik testi sonuçları } & \\
\hline & \multicolumn{3}{|c|}{ Ki-kare $(\chi 2)$} & $: 259.716$ & \\
\hline & \multicolumn{3}{|c|}{ Serbestlik derecesi (sd) } & $: 1$ & \\
\hline & \multicolumn{3}{|c|}{ Anlamlılık düzeyi (p) } & $: 0.000$ & \\
\hline & 1 & 2.523 & 84.083 & 84.083 & \multirow{3}{*}{0.905} \\
\hline \multirow[t]{7}{*}{ KAL } & 2 & 0.281 & 9.383 & 93.466 & \\
\hline & 3 & 0.196 & 6.534 & 100.000 & \\
\hline & KMO & & & $: 0.749$ & \\
\hline & \multicolumn{4}{|c|}{ Bartlett küresellik testi sonuçları } & \\
\hline & \multicolumn{3}{|c|}{ Ki-kare $(\chi 2)$} & $: 852.231$ & \\
\hline & \multicolumn{3}{|c|}{ Serbestlik derecesi (sd) } & $: 3$ & \\
\hline & \multicolumn{3}{|c|}{ Anlamlılık düzeyi } & $: 0.000$ & \\
\hline
\end{tabular}

* Temel bileşenler faktör analizi, Varimax rotasyon metodu 


\section{Doğrulayıcı Faktör Analizi: Ölçme Modelinin Geçerliliği ve Güvenilirliği}

DFA kapsaminda, AFA ile tek boyutlulukları belirlenen yapıları açıklayan değişkenlerin ölçme modeli test edilmiştir. Bu aşamada, AFA analizi ile belirlenen faktör yapılarını niteleyen gözlenen değişkenlerin tümü analize alınmıştır. Model kapsamındaki 4 örtük değişkeni temsil eden 13 gözlenen değişken ile yapılan analizde, düşük standardize edilmiş parametre ve yüksek düzeyde hata değeri veren KAL3 değişkeni elenmiştir (Hau ve Thuy, 2011; Lin, 2011). Bunun sonucunda, 4 örtük değişkeni niteleyen 12 gözlenen değişkene ait elde edilen DFA sonuçlarına ilişkin değerler Tablo 4'de sunulmaktadır.

Tablo 4 kapsaminda DFA sonucunda elde edilen uyum iyiliği değerleri incelendiğinde, ölçme mode- linin analiz açısından uygun sonuçlar verdiği görülmektedir (Schermelleh-Engel vd., 2003). Ayrica, elde edilen değerler incelendiğinde, örtük değişkenler (yapılar) ile gözlenen değişkenler arasındaki standardize edilmiş parametre değerlerinin $(\beta)$ 0.50'den yüksek olması ve yine bu ilişkilerin yüksek $t$ değerlerinde olması ( $\mathrm{t}>2.576)$, ölçme modeli kapsamındaki tüm değişkenler için 0.01 düzeyinde anlamlı sonuçlar elde edildiğini göstermektedir. Bu kapsamda, standardize edilmiş parametre değerlerinin 0.59 'dan yüksek ve 0.01 düzeyinde anlamlı olmasına (Hair vd., 1998) ek olarak, yapı güvenilirliği değerlerinin de 0.50’nin üzerinde olması (Fornell ve Larcker, 1981), ölçme modelinin güvenilirliğini sağlanması açısından önemli kanıtlar olarak görülmüştür (Tablo 4 ve 5).

Tablo 4. Doğrulayıcı Faktör Analizi Sonuçları*

\begin{tabular}{lllll}
\hline $\begin{array}{l}\text { Örtük } \\
\text { değişkenler } \\
\text { (yapılar) }\end{array}$ & $\begin{array}{l}\text { Gözlenen } \\
\text { değişkenler }\end{array}$ & $\begin{array}{l}\text { Standardize } \\
\text { edilmiş } \\
\text { parametre } \\
\text { değeri }(\beta)\end{array}$ & t-değeri & $\begin{array}{l}\text { Standart hata } \\
\text { değeri }\end{array}$ \\
\hline & Güv1 & 0.82 & 20.10 & 0.34 \\
& Güv2 & 0.81 & 20.06 & 0.34 \\
GÜV & Güv4 & 0.85 & 21.56 & 0.27 \\
& Güv4 & 0.72 & 16.77 & 0.48 \\
& Güv5 & 0.63 & 14.11 & 0.60 \\
& Tat1 & 0.89 & 23.23 & 0.21 \\
TAT & Tat2 & 0.97 & 26.99 & 0.06 \\
& Tat3 & 0.72 & 17.05 & 0.49 \\
& Döe1 & 0.90 & 21.28 & 0.20 \\
DÖE & Döe2 & 0.77 & 17.65 & 0.40 \\
& Kal1 & 0.90 & 21.85 & 0.19 \\
KAL & Kal2 & 0.84 & 20.08 & 0.29 \\
& Kal3** & - & - & - \\
\hline
\end{tabular}

* Uyum iyiliği değerleri: $\mathrm{p}<0.05, \chi 2=141.72$, Serbestlik Derecesi $(\mathrm{sd})=48, \chi 2 / \mathrm{sd}=2.84$, RMSEA $=0.067, \mathrm{NFI}=0.96, \mathrm{NNFI}=0.96, \mathrm{CFI}=0.97, \mathrm{IFI}=0.97, \mathrm{GFI}=0.95, \mathrm{AGFI}=$ 0.92, SRMR $=0.034$.

** DFA kapsamında elenen değişken 
Tablo 5. Güvenilirlik, Ayrım Geçerliliği ve Birleşme Geçerliliği*

\begin{tabular}{|c|c|c|c|c|c|}
\hline & Yap1 Güvenirliği (CR) & GUV & TAT & WPM & KAL \\
\hline GUV & 0.878 & 0.59 & & & \\
\hline TAT & 0.897 & $0.55\left(0.74^{L}\right)$ & 0.75 & & \\
\hline DÖE & 0.823 & $0.44\left(0.66^{L}\right)$ & $0.53\left(0.73^{L}\right)$ & 0.70 & \\
\hline KAL & 0.863 & $0.46\left(0.68^{2}\right)$ & $0.42\left(0.65^{\llcorner}\right)$ & $0.41\left(0.64^{2}\right)$ & 0.76 \\
\hline
\end{tabular}

Bunun yanı sıra, DFA kapsamında analiz edilen ölçüm modeli, yakınsama ve ayrım geçerliliğinin sağlanması açısından da değerlendirilmiştir. Bu doğrultuda, her bir yapıyı oluşturan gözlenen değişkenlerin ortalama açıklanan varyans değerlerinin önerilen s1nır değer olan 0.50 'den yüksek olması, yakınsama geçerliliğinin sağlandığ 1 konusunda önemli bir gösterge olarak görülmüştür (Bagozzi ve Yi, 1988, s. 82). Ayrım geçerliliğinin test edilmesinde ise Fornell ve Larcker (1981) tarafından önerilen referans değerler dikkate alınmıştır. Buna göre, örtük değişkenler arasındaki korelasyonların karelerinin (paylaşılan varyans değerlerinin), her bir yapı için ortalama açıklanan varyans değerinden düşük olduğu görülmektedir. $\mathrm{Bu}$ nedenle ölçme modelini oluşturan örtük değişkenler arasındaki ayrım geçerliliğinin de sağlandığı söylenebilmektedir (Tablo 5).

\section{Yapısal Model Kapsamında Doğrudan Etkilerin Değerlendirilmesi}

Araştırma kapsamında ele alınan modelin içerdiği doğrudan ilişkileri betimleyen yapısal modelin test edilmesi sonucu elde edilen değerler Tablo 6'da sunulmaktadır. Analiz sonucunda, araştırma modeli kapsamındaki tüm ilişkilerin en az 0.05 düzeyinde anlamlı ve model uyum iyiliği değerlerinin de kabul edilebilir sınırlar içerisinde olduğu görülmektedir (Schermelleh-Engel vd., 2003). Bu nedenle, model kapsamında sunulan doğrudan etkileri içeren tüm hipotezlerin (H1-H6) desteklendiği söylenebilir (Tablo 6).

Analiz sonucunda model tarafından üretilen değerler arasında GÜV, TAT ve DÖE açıllanma değerleri de bulunmaktadır. Bu kapsamda araştırma modelinin 0.58 düzeyinde hastaların daha fazla ödeme eğilimini açılladığı görülmektedir $\left(\mathrm{R}_{\text {DÖE }}^{2}\right)$.

Tablo 6. Standardize Edilmiş Çözüm ve Uyum Iyiliği Değerleri ${ }^{A}$

\begin{tabular}{|c|c|c|c|c|c|}
\hline Hipotezler & Doğrudan etkiler & $\beta$ & t-değeri & Sonuçlar & Açlklanma deg̊eri \\
\hline H1 & $\mathrm{KAL} \rightarrow \mathrm{TAT}$ & 0.65 & $13.17^{* *}$ & Desteklendi & $\mathrm{R}_{\mathrm{GÜV}}^{2}=0.62$ \\
\hline $\mathrm{H} 2$ & $\mathrm{KAL} \rightarrow \mathrm{GÜV}$ & 0.33 & $6.04 * *$ & Desteklendi & $\mathrm{R}_{\mathrm{TAT}}^{2}=0.43$ \\
\hline H3 & $\mathrm{KAL} \rightarrow$ DÖE & 0.23 & $3.57 * *$ & Desteklendi & $\mathrm{R}_{\mathrm{DÖE}}^{L}=0.58$ \\
\hline $\mathrm{H} 4$ & $\mathrm{TAT} \rightarrow \mathrm{GUVV}$ & 0.53 & $9.56^{* *}$ & Desteklendi & \\
\hline H5 & $\mathrm{TAT} \rightarrow$ DÖE & 0.45 & $6.70^{* *}$ & Desteklendi & \\
\hline $\mathrm{H} 6$ & GÜV $\rightarrow$ DÖE & 0.17 & $2.37^{*}$ & Desteklendi & \\
\hline
\end{tabular}


Tablo 7. Yapılar Arasındaki ilişsilerin Toplam Etkileri ${ }^{A}$

\begin{tabular}{|c|c|c|c|c|}
\hline & KAL & GUV & TAT & DOE \\
\hline KAL & & $0.68(12.82)$ & $0.65(13.17)$ & $0.64(12.37)$ \\
\hline GÜV & --- & & & $0.17(2.37)$ \\
\hline TAT & --- & $0.53(9.56)$ & & $0.54(9.44)$ \\
\hline DÖE & --- & --- & --- & \\
\hline
\end{tabular}

Araştırma modeli kapsamında sunulan yapısal ilişkilerin toplam etkilerinin hesaplanması sonucu elde edilen değerler Tablo 7'de sunulmuştur. Bu değerlerin incelenmesi ile doğrudan ilişkilerin yanı sıra, model kapsamında ortaya çıkan dolaylı etkilerin de değerlendirilebilmesi mümkün olmaktadır. Bu kapsamda, DÖẺnin oluşumunda doğrudan ve dolaylı etkiler beraberce değerlendirildiğinde, sırasıyla KAL, TAT ve GÜV değişkenlerinin etkili olduğu görülmektedir. Bununla birlikte, KAL değişkenin toplam etkisi değerlendirildiğinde, TAT üzerindeki doğrudan etkisinin yanı sıra GÜV üzerindeki toplam etkisinin yüksek olduğu da elde edilen sonuçlar arasındadır $\left(\beta_{\text {KAL } \rightarrow \text { GUVV }}=0.53, \mathrm{t}=9.96\right)$.

\section{Düzenleyici Etkilerin Test Edilmesi: Hastane Seçimi}

Araştırma modelinin barındırdığı doğrudan ve dolaylı etkilerin test edilmesinden sonra, hastaların daha fazla ödeme eğilimlerinin oluşumunu inceleyen model kapsamındaki ilişkiler arasında öne sürülen düzenleyici etkiler test edilmiştir. Bu amaca yönelik olarak Homburg ve Giering (2001) ve Evanschitzky ve Wunderlich (2006) tarafından önerilen yaklașım tercih edilmiş ve Çoklu Grup Düzenleyici etki (Multi-Group Moderation) testi uygulanmıştır.

$\mathrm{Bu}$ kapsamda, öncelikle düzenleyici değişken olarak modelde test edilmek istenen hastane tercihi değişkeni kullanılarak, veri seti iki kısma ayrılmıştır. Bu aşamadan sonra, düzenleyici değişkenin, modelin barındırdığ amacıyla; düzenleyici değişkenin model kapsamındaki etkilerini bütüncül olarak değerlendirebilmek için ki-kare farklılık testi yapılmıştır. Bu analiz kapsamında modelin barındırdığı tüm ilişkiler, oluşturulan alt gruplar (devlet hastanesini tercih edenler ve özel hastaneyi tercih edenler) kapsamında topluca karşılaşt1- rılmaktadır. Burada, araştırma modelindeki devlet ve özel hastane tercihlerinin oluşturduğu alt grupların etkisi, genel model, yani sınırlandırılmamış olan model ile karşılaştırmıştır. Analiz sonucunda elde edilen ki-kare değeri, yine elde edilen serbestlik derecesi değeri ile karşılaştırılarak düzenleyici değişkenin etkisi test edilmiştir. Bu şekilde, hastane tercihi düzenleyici değişkenin etkisi, tüm model kapsamında test edilmiştir.

Bu aşamada, devlet hastanesini tercih eden alt grup, özel hastaneyi tercih eden alt grup ve alt gruplar açısından sınırlandırılmamış veri setinin, model kapsamında analizi sonucunda elde edilen ki kare değerinin 57.73, serbestlik derecesi değerinin ise 18 olduğu görülmüştür [ $\Delta \chi 2$ (sd = 18): 57.73]. Daha sonra, serbestlik derecesi değerinin ki-kare değeri ile karşılaşt1rılması ile hastane tercihi değişkeninin model kapsamındaki ilişkiler üzerinde düzenleyici etkileri olduğu tespit edilmiştir? . Bu anlamda, araştırma modeli kapsamında hastane tercihinin düzenleyicilik etkisi değerlendirildiğinde, özel hastanede sunulan sağlık hizmetini alan hastaların, devlet hastanesini tercih edenlere göre ödeme eğilimlerinin farklılaştığı tespit edilmiştir. Bu nedenle, H7'nin genel anlamda desteklendiği söylemek mümkün olmaktadır.

Ancak, düzenleyici değişkenin tüm model üzerinde etkili olduğunun ya da bir diğer ifadeyle, örneklem alt gruplarının model kapsamındaki belirli ilişkilerin farklılaşmasına yol açtı̆̆ının tespit edilmesi, bu farklı-

7 Burada, serbestlik derecesi 18 olan modelin ki-kare değeri, önerilen sınır ki-kare değeri olan 34.81 değeri ile karşılaştırılması yapılmaktadır. Elde edilen ki-kare değerinin (57.73), önerilen sınır değer olan 34.81'den yüksek çıkması, alt gruplar ve sınırlandırılmamış model kapsamında düzenleyici etkinin istatistiki olarak 0.01 düzeyinde farklllık gösterdiğini ortaya koymaktadır. 
lığın hangi ilişkilerde ve hangi alt gruplarda meydana geldiğini göstermemektedir. Bu nedenle, model kapsamındaki ilişkilerin düzenleyici değişken tarafından farklılaştığının tespit edilmesinden sonra, gözlenen değişkenler arasındaki ilişkiler, yani hipotezler, çerçevesinde alt gruplar arasındaki farklılıkların değerlendirilmesi gerekmektedir. Bu kapsamda, her bir alt grup için ilişkiler analiz edilerek ki-kare farklılık testi yapılmaktadır. Söz konusu karşılaştırmada, 0.05 anlamlılık düzeyinde, serbestlik derecesi 1 için ki-kare sınır değeri 3.84 olmaktadır $\left(\Delta \chi^{2} \geq 3.84\right.$, sd $\left.=1\right)$.
Hastane tercihi düzenleyici değişkenin araştırma modeli kapsamındaki etkilerine ilişkin sonuçlar tablo 8 'de sunulmaktadir.

Çoklu grup düzenleyici etki testi analiz sonuçlarını gösteren tablo incelendiğinde (Tablo 8), hasta tatmin düzeyi ile güven düzeyi arasındaki ilişki $\left(\mathrm{H} 7_{\mathrm{d}}\right.$ : TAT $\rightarrow$ GÜV) haricindeki tüm düzenleyici etki hipotezlerinin desteklendiği görülmektedir $\left(\mathrm{H}_{\mathrm{a}}, \mathrm{H} 7_{\mathrm{b}}, \mathrm{H} 7_{\mathrm{c}}, \mathrm{H} 7_{\mathrm{e}}\right.$ ve $\mathrm{H}_{\mathrm{f}}$ ). Tüm bu ilişkiler çerçevesinde, özel hastaneyi tercih eden hastaların etki düzeylerinin devlet hastanesini tercih edenlerden daha üst düzeyde olduğu tespit edilmiştir.

Tablo 8. Çoklu Grup Düzenleyici Etki Testi Sonuçları

\begin{tabular}{|c|c|c|c|c|c|c|c|}
\hline \multirow{2}{*}{ Hipotezler } & \multirow{2}{*}{ Hastane tercihi } & \multicolumn{2}{|c|}{ Devlet } & \multicolumn{2}{|l|}{ Ozel } & \multirow[b]{2}{*}{$\begin{array}{l}\text { Ki-kare fark1 } \\
(\Delta \mathrm{sd}=1)\end{array}$} & \multirow{2}{*}{ Sonuçlar } \\
\hline & & $\beta$ & $\begin{array}{l}\mathrm{t}- \\
\text { değeri }\end{array}$ & $\beta$ & t-değeri & & \\
\hline $\mathrm{H}_{\mathrm{a}}$ & $\mathrm{KAL} \rightarrow \mathrm{TAT}$ & 0.64 & 7.26 & 0.87 & 12.04 & $13.2^{*}$ & Desteklendi \\
\hline $\mathrm{H} 7_{\mathrm{b}}$ & $\mathrm{KAL} \rightarrow \mathrm{GÜV}$ & 0.72 & 6.70 & 0.85 & 12.44 & $12.55^{*}$ & Desteklendi \\
\hline $\mathrm{H} 7_{\mathrm{c}}$ & $\mathrm{KAL} \rightarrow \mathrm{DÖE}$ & 0.55 & 5.12 & 0.74 & 9.88 & $4.98 *$ & Desteklendi \\
\hline $\mathrm{H} 7_{\mathrm{d}}$ & $\mathrm{TAT} \rightarrow \mathrm{GÜV}$ & 0.63 & 6.57 & 0.84 & 12.50 & 1.53 & Desteklenmedi \\
\hline $\mathrm{H} 7_{\mathrm{e}}$ & $\mathrm{TAT} \rightarrow \mathrm{DÖE}$ & 0.69 & 8.06 & 0.87 & 13.29 & $24.43^{*}$ & Desteklendi \\
\hline \multirow[t]{2}{*}{$\mathrm{H} 7_{\mathrm{f}}$} & GÜV $\rightarrow$ DÖE & 0.52 & 5.45 & 0.79 & 11.82 & $16.71^{*}$ & Desteklendi \\
\hline & Tüm model değeri (H7): & \multicolumn{5}{|c|}{$\Delta \chi^{2}(\mathrm{sd}=18): 57.73^{* *}$} & \\
\hline
\end{tabular}

\section{Tartışma ve Sonuç}

$\mathrm{Bu}$ çalışma tüketici davranışı perspektifinde, kurumsal güven, tatmin düzeyi ve algılanan hizmet kalitesi değişkenleri arasındaki etkileşimler kapsamında hastaların daha fazla ödeme eğilimlerinin oluşumunun açıllanabileceğine dair önemli kanıtlar sunmaktadır. Çalışma, sonuçları itibariyle, hastaların daha fazla ödeme eğilimlerinin oluşumunda, algılanan hizmet kalitesinin ödeme eğilimi oluşumu üzerinde hem doğrudan hem de dolaylı etkilere sahip olduğunu ortaya koymaktadır. Hizmet değerlendirme süreci modellerini alternatif ilişkiler çerçevesinde test eden çalışmalarda da (Cronin vd., 2000; Brady vd., 2005) benzer sonuçları görmek mümkündür. Bu nedenle, hastaların sağlık hizmetlerinden algıladıkları kalite düzeylerinin hizmetin ekonomik bedelinin yanı sıra, hizmet alımı sonucunda elde ettikleri tatmin düzeyi ve hizmet sunan sağlik kurumuna ilişkin güven düzeylerinin oluşumunda da belirleyici etkisi bulunmaktadır.

Hastaların sağlık hizmetlerine olan taleplerinde daha fazla ödeme eğilimlerinin belirlenmesinde, algılanan kalite düzeyinin yanı sıra, tatmin düzeylerinin de etkili olduğu görülmektedir. Benzer şekilde Choi vd. (2004) ve Dursun ve Çerçi (2004) tarafından yapılan çalışmalardan elde edilen bulgular kapsamında da hastaların davranışsal niyetlerinin oluşumunda kalite düzeylerinin yanı sıra tatmin düzeylerinin de yüksek derecede etkili olduğu ortaya konmaktadır. Bu kapsamda, sağlık hizmeti sunun kuruluşlarda yapılan 
Toplam Kalite Yönetimi uygulamalarının, hasta yönlü çıtılarının değerlendirilmesinin önemli olduğu söylenebilir.

Roew ve Calnan (2006, s. 6)'in görüşüne paralel bir şekilde, bu çalışma kapsamında hastaların hizmet taleplerinin ekonomik yönünü değerlendirilmektedir. Araştırma modeli kapsamında, özellikle kurumsal güvenin oluşumu açısından algılanan kalite ve tatmin düzeylerinin belirleyici etkileri olduğu tespit edilmesine rağmen; güven unsurunun, daha fazla ödeme davranışı üzerindeki etkisinin diğer değişkenler ile kıyaslandığında göreceli olarak sınırlı kaldığı da görülmektedir (Tablo 6 ve 7). Ancak, Çınaroğlu ve Şahin (2012) tarafından yapılan çalışmada, özellikle kurumsal itibarının ve imajının, hastanelerin performansı üzerinde etkili olduğu da belirtilmektedir. Bu nedenle, Gilson $(2003$; 2006) ile paralel bir şekilde, sağlık hizmetlerinde güven unsuru ve bunun hastaların ödeme davranışının oluşumu üzerindeki etkisinde güven duygusu, kurumsal olduğu kadar, genel sağlık sistemi çerçevesinde ele alınması gereken bir konu olarak görülmektedir.

Hastaların daha fazla ödeme eğiliminin oluşumu, sağlık hizmeti sunan kurum açısından değerlendirildiğinde, özel hastaneleri tercih eden hastaların daha fazla ödeme eğilimlerinin oluşmasında, devlet hastanesini tercih eden hastalara oranla farklılıklar tespit edilmiştir. Araştırma modeli kapsamında sunulan tatmin ve kurumsal güven düzeyi arasındaki ilişki haricindeki tüm ilişkilerde, özel hastanede sunulan hizmete dönük algıların daha fazla ödeme eğiliminin oluşumunda daha etkili olduğu gözlenmiştir. Bu paralelde çalışma kapsamında, hastaların tatmin düzeyinin kurumsal güven düzeyini etkilediği ve bu etkinin özel ve kamu sahipliğindeki hastaneler açısından farklılaşmadığı da ortaya çıkan sonuçlardandır. Bu nedenle, algılanan kalite ve tatmin düzeyi arasındaki etkileşimin, hastaların tedavi ve muayene ücretlerine olan algısında, özel sağlık kuruluşlarına olan ödeme eğilimlerini büyük oranda desteklediğini belirtmek mümkün olmaktadır.

Sağlık hizmetlerinin yerine getirilmesi açısından kamunun, sektörde düzenleyici ve uygulayıcı olmak üzere iki farklı rolde olduğu görülmektedir. Düzenleme etkisi bakımından, sağlık politikaları ve genel sağlık hizmetlerinin sürdürülebilir bir şekilde yürütülmesi ile yükümlü olan devlet, bir yandan da kurumları aracıllğıyla sektörde özel hastaneler ile bera- ber etkin olarak yer alan başlıca aktör konumundadır. $\mathrm{Bu}$ açıdan, piyasalaşma sürecinde olan sağlık sektöründe, genel sağlık politikalarının yanı sıra gerek kamu gerekse de özel sağlık kurumlarının, sistemin finansman temel kaynağını teşkil eden müșterilerinin ihtiyaç ve beklentilerinin karşılaması gerekmektedir.

Sağlık hizmetlerinde, diğer sektörler ile karşılaştırıldığında, salt olarak hasta-müşteri eşleştirilmesini yapılması ise olumsuz sonuçlar doğurabilmektedir. Hasta açısından algılanan kalite, tatmin ve dolayısıyla güven düzeyinin oluşumu, sunulan tedavi ve muayene hizmetinin tıbbi kalitesinden bağımsızdır. Başka bir ifadeyle, daha fazla ödeme eğiliminin oluşumunda, hasta algıları ve beklentileri ön plandadır ve hastalar, sunulan sağlık hizmetinin yanı sıra hekimin tedavi ve ilaç bilgisinin yeterliliği yönündeki algılarını, tatmin düzeylerinde (Sitzia ve Wood, 1997) ve dolay1sıyla ödeme davranışlarında değerlendirmektedirler. Piyasa süreci kapsamında şekillenecek olan bu sistem de, özellikle daha fazla ücret talep eden özel hastanelerin hizmetlerini, tıbbi gereklerden çok, hasta beklenti ve istekleri üzerinde yoğunlaştırmalarına neden olabilecektir. Bu nedenle, Ovreveit (1996) ile paralel bir şekilde, gerek tatmin gerekse de algilanan kalitenin oluşumunda belirleyici olan sağlik hizmetleri konusundaki bilgilendirme faaliyetlerinin, etkin bir şekilde yapılarak, hizmet alan hastaların daha doğru ve fonksiyonel değerlendirme yapabilmelerinin sağlanması gerektiği düşünülmektedir.

$\mathrm{Bu}$ çalışma, sağlık hizmetleri açısından hastaların daha fazla ödeme eğilimleri konusunda literatüre ve uygulamaya dönük katkılar barındırmasına rağmen, belirli kısitlara da sahiptir. Bunlardan ilki, hizmet sürecinin ele alınması açsısından müşteri değeri kavramının çalışmanın dışında tutulmasıdır. Hizmet pazarlaması perspektifinde hizmet sürecini değerlendiren modellerde (örn., Brady vd., 2005; Zhag ve Bloomer, 2008) yoğun bir şekilde ele alınan bu kavram, sağlık hizmetleri konusundaki yapılan çalışmalarda ekseriyetle değerlendirme dışı bırakılmıştır. Bu nedenle, sonraki çalışmalarda müşteri değeri kavramının hasta boyutuyla ele alınmasının faydalı ve gerekli olduğu düşünülmektedir. Bununla beraber bu çalışma, hastaların daha fazla ödeme eğilimlerinin oluşumunu, kurumsal açıdan kalite, tatmin ve güven düzeyinde ele almıştır. Ancak, özellikle sağlık hizmetleri açısından, bu değişkenlerin kişiler arası etkileşime (hekim-hasta ilişkisi) dayanan farklı boyutları da bulunmaktadır. $\mathrm{Bu}$ nedenle, sonraki çalışmalarda, daha fazla öde- 
me eğilimin oluşumu açısından, hekim, diğer sağlık personeli ve hasta arasındaki ilişkiye odaklanılabileceği de düşünülmektedir. Bu kapsamda, özellikle, son ylllarda kamu hastanelerinde uygulamaya konulan hekim seçme hakkı uygulamasının, kurumsal güvenin oluşumuna olduğu kadar daha fazla ödeme eğiliminin belirlenmesi açısından incelenmesinin de yararlı olabileceği önerilmektedir. Son olarak ise, bu çalışma Çankırı ili örneklemindeki hastalara kapsamında yapılmıştır. Farklı sosyo-ekonomik düzeydeki örneklemlerde ve sağlık kurumlarında yapılacak olan çalışmalarda değişik sonuçlar elde edilmesi de olası bir durum olarak değerlendirilmelidir. Bu nedenle, bu çalışmanın sonuçları kapsamında önerilen araştırma modelinin, farklı nitelikteki sağlık kuruluşlarında (ihtisas hastaneleri, sağlık ocakları vb.) test edilmesi ile literatüre olduğu kadar uygulamaya da katkı sağlanabileceği düşünülmektedir.

\section{Kaynakça}

Adjei, M. T., Clark, M. N. (2010). Relationship Marketing in A B2C Context: The Moderating Role of Personality Traits. Journal of Retailing and Consumer Services, 17, 73-79.

Akbar, M., Parvez, N. (2009), Impact of Service Quality, Trust, and Customer Satisfaction on Customers Loyalty. ABAC Journal, 29 (1), 24-38.

Alhabeeb, M. J. (2007). On Consumer Trust and Product Loyalty. International Journal of Consumer Studies. 31 (6), 609-612.

Altay, A. (2007). Sağlık Hizmetlerinin Sunumunda Yeni Açılımlar ve Türkiye Açısından Değerlendirilmesi. Sayıştay Dergisi, 64, Ocak-Mart.

Andaleeb, S. S. (2000). Service Quality in Public and Private Hospitals in Urban Bangladesh: A Comparative Study. Health Policy, 53, 25-37.

Andaleeb, S. S. (2001). Service Quality Perceptions and Patient Satisfaction: A Study of Hospitals in a Developing Country. Social Science \& Medicine, 52, 1359-1370.

Anderson, E. W. (1996). Customer Satisfaction and Price Tolerance. Marketing Letters, 7 (3), 265-74.
Athanassopoulos, A. D. (2000). Customer Satisfaction Cues to Support Market Segmentation and Explain Switching Behavior. Journal of Business Research, 47, 191-207.

Bagozzi, R. P., Yi, Y. (1988). On the Evaluation of Structural Equation Models. Journal of the Academy of Marketing Science, 16 (1), 74-95.

Baji, P., Pavlova, M., Gulácsi, L., Groot, W. (2012). Preferences of Hungarian Consumers for Quality, Access and Price Attributes of Health Care Services - Result of a Discrete Choice Experiment. Society and Economy, 34 (2), 293-311.

Baker, D. A., Crompton, J. L. (2000). Quality, Satisfaction and Behavioral Intentions. Annals of Tourism Research, 27 (3), 785-804.

Bartlett, H. P., Phillips, D. R. (1996). Policy Issues in the Private Health Sector: Examples from LongTerm Care in the U.K. Social Science \& Medicine, 43 (5), 731-737.

Blanchard, C. G., Labrecque, M. S., Ruckdeschel, J. C., Blanchard, E. B. (1990). Physician Behaviors, Patient Perceptions, and Patient Characteristics as Predictors of Satisfaction of Hospitalized Adult Cancer Patients. Cancer, 65 (1), 186-92.

Bloemer, J., de Ruyter, K., Wetzels, M. (1999). Linking Perceived Service Quality and Service Loyalty: A Multi-Dimensional Perspective. European Journal of Marketing, 33, 1082-1106.

Bolton, R. N., Lemon, K. N. (1999). A Dynamic Model of Customers' Usage of Services: Usage as an Antecedent and Consequence of Satisfaction. Journal of Marketing Research. 36 (May), 171-186.

Boulding, W., Kalra, A., Staelin, R., Zeithaml, V. (1993). A Dynamic Process Model of Service Quality: Form Expectations to Behavioral Intentions. Journal of Marketing Research, 30, 7-27.

Bowers, M. R., Swan, J. E., Koehler, W. (1994). What Attributes Determine Quality and Satisfaction with Health Care Delivery. Health Care Management Review, 19 (4), 49-55.

Brady, M. K., Cronin, J. J. (2001). Some New Thoughts on Conceptualizing Perceived Service Quality: A Hierarchical Approach. Journal of Marketing, 65 (July), 34-49. 
Brady, M. K., Knight, G. A., Cronin, J. J., Tomas, G., Hult, M., Keillor, B. D. (2005). Removing the Contextual Lens: A Multinational, Multi-Setting Comparison of Service Evaluation Models. Journal of Retailing, 81 (3), 215-230.

Brown, S. W., Swartz, T. A. (1989). A Gap Analysis of Professional Service Quality. Journal of Marketing, 53 (2), 92-98.

Buchanan, A.E. (2000). Trust in Managed Care Organizations. Kennedy Institute of Ethics Journal, 10 (3), 189-212.

Caceres, R. C., Paparoidamis, N. G. (2007). Service Quality, Relationship Satisfaction, Trust, Commitment and Business-to-Business Loyalty. European Journal of Marketing, 41 (7/8), 836-867.

Carman, J. M. (2000). Patient Perceptions of Service Quality: Combining the Dimensions. Journal of Services Marketing, 14 (4), 337-352.

Chaudhuri, A., Holbrook, M. B. (2001). The Chain of Effects from Brand Trust and Brand Affect to Brand Performance: The Role of Brand Loyalty. Journal of Marketing, 65 (2), 81-93.

Chiou, J. S., Droge, C. (2006). Service Quality, Trust, Specific Asset Investment, and Expertise: Direct and Indirect Effects in a Satisfaction-Loyalty Framework. Journal of the Academy of Marketing Science, 34 (4), 613-627.

Choi, K. S., Cho, W. H., Lee, S. L., Lee, H., Kim, C. (2004). The Relationships Among Quality, Value, Satisfaction and Behavioral Intention in Health Care Provider Choice: A South Korean Study. Journal of Business Research, 57, 913-921.

Cronin, J. J., Brady, M. K., Brand, R. R., Hightower, R., Shemwell, D. J. (1997). A Cross-Sectional Test of the Effect and Conceptualization of Service Value. The Journal of Services Marketing, 11 (6), 375-391.

Cronin, J. J., Brady, M. K., Hult, M. (2000). Assessing the Effects of Quality, Value and Customer Satisfaction on Consumer Behavioral Intentions in Service Encounters. Journal of Retailing, 76 (2), 193-218.

Cronin, J. J., Taylor, S. A. (1992). Measuring Service Quality: A Reexamination and Extension. Journal of Marketing, 56 (3), 55-68.
Dabholkar, P., Thorpe, D. I., Rentz, J. O. (1996). A Measure of Service Quality for Retail Stores. Journal of the Academy of Marketing Science, 24 (Winter), 3-16.

Delgado-Ballester, E., Munuera-Aleman, J. L. (2001). Brand Trust in the Context of Consumer Loyalty. European Journal of Marketing, 35 (11/12), 12381258.

Deniz, M. H., Hobikoğlu, E. H. (2011). Türkiye'de "Değere Bağlı Sağlık Sistemi" Temelinde Kamu ve Özel Sektör Açısından Algılanan Hizmet Kalitesi. International Conference on Eurasian Economies, 12-14 October 2011 - Bishkek, KYRGYZSTAN.

Doney, P. M., Cannon, J. P. (1997). An Examination of the Nature of Trust in Buyer-Seller Relationships. Journal of Marketing, 61 (2), 35-51.

Dufrene, R. L. (2000). An Evaluation of a Patient Satisfaction Survey: Validity and Reliability. Evaluation and Program Planning, 23, 293-300.

Dölarslan, E. Ş. (2012). Seçim Seti Teorisi Çerçevesinde Tüketici Satın Alma Karar Süreci. Eskişehir Osmangazi Üniversitesi İIBBF Dergisi, 7 (1), 7-37.

Dursun, Y., Çerçi, M. (2004). Algılanan Sağlık Hizmeti Kalitesi, Algılanan Değer, Hasta Tatmini ve Davranışsal Niyet İlişkileri Üzerine Bir Araştırma. Erciyes Üniversitesi İktisadi ve İdari Bilimler Fakültesi Dergisi, 23 (Temmuz-Aralı), 1-16.

Eisingerich, A. B., Bell, S. J. (2008). Perceived Service Quality and Customer Trust: Does Enhancing Customers' Service Knowledge Matter? Journal of Service Research, 10 (3), 256-268.

Evanschitzky, H., Wunderlich, M. (2006). An Examination of Moderator Effects in the Four-Stage Loyalty Model. Journal of Service Research, 8, 330-345.

Fornell, C., Larcker, D. F. (1981). Evaluating Structural Equation Models with Unobservable Variables and Measurement Error. Journal of Marketing Research, 18 (1), 39-50.

Francis, J.E. (2007). Internet Retailing Quality: One Size Does Not Fit All, Managing Service Quality, 17 (3), 341-55.

Garbarino, E., Johnson, M. S. (1999). The Different Roles of Satisfaction, Trust, and Commitment in Customer Relationships. Journal of Marketing, 63 (2), 70-87. 
Gilson, L. (2003).Trust and the Development of Health Care as a Social Institution. Social Science \& Medicine, 56, 1453-1468.

Goold, S. D., Klipp, G. (2002). Managed Care Members Talk About Trust. Social Science \& Medicine, $54,879-888$.

Gotlieb, J. B., Grewal, D., Brown, S. W. (1994). Consumer Satisfaction and Perceived Quality: Complementary or Divergent Constructs? Journal of Applied Psychology, 79 (6), 875-885.

Grönroos, C. (1984). A Service Quality Model and Its Marketing Implications, European Journal of Marketing, 18 (4), 36-44.

Günaydın, D. (2011). Sağlık Hizmetlerinde Küresel Reform Yaklaşımları. Sosyal Siyaset Konferansları Dergisi, 60 (1), 323-365.

Hair, J.F., Anderson, R. E., Tatham, R. L., Black, W. C. (1998). Multivariate Data Analysis. Prentice-Hall, New Jersey, USA.

Hall, M. A., Dugan, E., Zheng, B., Mishra, A. K. (2001). Trust in Physicians and Medical Institutions: What is it, Can it Be Measured, and Does it Matter? Milbank Quarterly, (4), 613-639.

Harris, L. C., Goode, M. M. H. (2004). The Four Levels of Loyalty and the Pivotal Role of Trust: A Study of Online Service Dynamics. Journal of Retailing, 80, 139-158.

Hau, L. N., Thuy, P. N. (2011). Impact of Service Personal Values on Service Value and Customer Loyalty: A Cross-Service Industry Study. Service Business, 3, 293-307.

Homburg, C., Giering, A. (2001). Personal Characteristics as Moderators of the Relationship Between Customer Satisfaction and Loyalty: An Empirical Analysis. Psychological Marketing, 18 (1), 43-66.

Homburg, C., Koschate, N., Hoyer, W. D. (2005). Do Satisfied Customers Really Pay More?: A Study of the Relationship Between Customer Satisfaction and Willingness to Pay. Journal of Marketing, 69 (2), 84-96.

Hong, S., Malik, M. L., Lee, M. K. (2003). Testing Configural, Metric, Scalar, and Latent Mean Invariance Across Genders in Sociotropy and Autonomy Using a Non-Western Sample. Educational and Psychological Measurement, 63 (4), 636-654.
Hopkins, A. (1990). Measuring the Quality of Medical Care. Royal College of Physicians, London.

Hupcey, J. E., Miller, J. (2006). Community Dwelling Adults' Perception of Interpersonal Trust vs. Trust in Health Care Providers. Journal of Clinical Nursing, 15 (9), 1132-1139.

Hutchinson, J., Lai, F., Wang, Y. (2009). Understanding the Relationships of Quality, Value, Equity, Satisfaction and Behavioral Intentions Among Golf Travelers. Tourism Management, 30, 298-308.

Ibáñez, V. A., Hartmann, P., Calvo, P. Z. (2006). Antecedents of Customer Loyalty in Residential Energy Markets: Service Quality, Satisfaction, Trust and Switching Costs, The Service Industries Journal, 26 (6), 633-650.

Jacoby, J., Kyner, D. B. (1973). Brand Loyalty Versus Repeat Purchasing. Journal of Marketing Research, 10 (February), 1-9.

Johnson, D., Grayson, K. (2005). Cognitive and Affective Trust in Service Relationships. Journal of Business Research, 58, 500-507.

Kalish, S., Nelson, P. (1991). A Comparison of Ranking, Rating and Reservation Price Measurement in Conjoint Analysis. Marketing Letters, 2 (4), 327335.

Kassim, N., Abdullah, N. A. (2010). The Effect of Perceived Service Quality Dimensions on Customer Satisfaction, Trust, and Loyalty, in E-Commerce Settings: A Cross Cultural Analysis. Asia Pacific Journal of Marketing and Logistics, 22 (3), 351-371.

Kao, A. C., Green, D. C., Zaslavsky, A. M., Koplan, J. P., Cleary, P. D. (1998). The Relationship Between Method of Physician Payment and Patient Trust. The Journal of American Medical Association, 280 (19), 1708-1714.

Kim, S. S., Kaplowitz, S., Johnston, M. V. (2004). The Effects of Physician Empathy on Patient Satisfaction and Compliance. Evaluation \& The Health Professions, 27 (3), 237-251.

Kohli, R., Mahajan, V. (1991). A Reservation-Price Model for Optimal Pricing of Multiattribute Products in Conjoint Analysis. Journal of Marketing Research, 28 (3), 347-354. 
Kraetschmer, N., Sharpe, N., Urowitz, S., Deber, R. B. (2004). How Does Trust Affect Patient Preferences for Participation in Decision-Making? Health Expectations, 7, 317-326.

Krishna, A. (1991). Effect of Dealing Patterns on Consumer Perceptions of Deal Frequency and Willingness to Pay. Journal of Marketing Research, 28 (4), 441-451.

Kucukarslan, S. N., Nadkarni, A. (2008). Evaluating Medication-Related Services in a Hospital Setting Using the Disconfirmation of Expectations Model of Satisfaction. Research in Social and Administrative Pharmacy, 4, 12-22.

Li, H. H. (2011). Gender Differences in the Linkage of Online Patronage Behaviour with TV-and-Online Shopping Values. Service Business, 5, 295-312.

Linder-Pelz, S. (1982). Toward a Theory of Patient Satisfaction. Social Science \& Medicine, 16 (5), 577582.

Loiacono, E. T., Watson, R. T., Goodhue, D. L. (2002). WebQual: A Measure of Web Site Quality, in, Proceedings of the Winter Educator's Conference, American Marketing Association, Chicago, IL, 432-437.

Lynn-McHale, D. J., Deatrick, J. A. (2000). Trust Between Family and Health Care Provider. Journal of Family Nursing, 2000, 6 (3), 210-230.

Magee, H., Davis, L. J., Coulter, A. (2003). Public Views on Healthcare Performance Indicators and Patient Choice. Journal of the Royal Society and Medicine, 96, 338-342.

Mainous A. G., Baker, R., Love, M. M., Gray, D. P., Gill, J. M. (2001). Continuity of Care and Trust in One's Physician: Evidence from Primary Care in the United States and the United Kingdom. Family Medicine, 33 (1), 22-27.

Mechanic, D. (1998). The Functions and Limitations of Trust in the Provision of Medical Care. Journal of Health Politics, Policy and Law, 23 (4), 661-686.

Mohseni, M., Lindstrom, M. (2007). Social Capital, Trust in The Health-Care System and Self-Rated Health: The Role of Access to Health Care in a Population-Based Study. Social Science \& Medicine, 64, 1373-1383.
Moorman, C., Deshpandé, R., Zaltman, G. (1993). Factors Affecting Trust in Market Research Relationships. Journal of Marketing, 57 (1), 81-101.

Morgan, R. M., Hunt, S. D. (1994). The CommitmentTrust Theory of Relationship Marketing. Journal of Marketing, 58 (3), 20-38.

Mummalaneni, V., Gopalakrishna, P. (1997). Access, Resource, and Cost Impacts on Consumer Satisfaction with Health Care: A Comparison Across Alternative Health Care Modes and Time. Journal of Business Research, 39, 173-186.

Oliver, R. L. (1980). A Cognitive Model of the Antecedents and Consequences of Satisfaction Decisions. Journal of Marketing Research, 17, 460-469.

Oliver, R. L., (1999). Whence Consumer Loyalty?" Journal of Marketing, 63, 33-44.

Ovretveit, J. (1996). Informed choice?- Health service quality and outcomeinformation for patients. Health Policy, 37, 75-90.

Özen, Ü., Çam, H., Aslay, F. Y. (2011). Kalite Boyutları ve Sağlık Hizmeti Unsurları Açısından Hasta Memnuniyetine Bir Bakış: Gümüşhane Devlet Hastanesi'nde Örnek Uygulama, Akademik Yaklaşımlar Dergisi, 2 (1).

Papatya, G., Papatya, N., Hamşığlu, A. B. (2012). Sağlık İşletmelerinde Algılanan Hizmet Kalitesi ve Hasta Memnuniyeti: İki Özel Hastanede Karşılaştırmalı Bir Araştırma. Kırıkkale Üniversitesi Sosyal Bilimler Dergisi, 2 (1), 87-108.

Parasuraman, A., Zeithaml, V. A., Berry, L. L. (1985). A Conceptual Model of Service Quality and Its Implications for Future Research. Journal of Marketing, 49, 41-50.

Parasuraman, A., Zeithaml, V. A., Berry, L. L. (1988). SERVQUAL: A Multiple-Item Scale for Measuring Consumer Perceptions of Service Quality. Journal of Retailing, 64 (1), 12-40.

Parasuraman, A., Zeithaml, V. A., Berry, L. L. (1994). Reassessment of Expectations as a Comparison Standard in Measuring Service Quality: Implications for Future Research. Journal of Marketing, 58, 111-124. 
Pearson, S. D., Raeke, L. H. (2000). Patients' Trust in Physicians: Many Theories, Few Measures and Little Data. Journal of General Internal Medicine, 15 (7), 509-513.

Piette, J. D., Heisler, M., Krein, S., Kerr, E. A. (2005). The Role of Patient-Physician Trust in Moderating Medication Nonadherence Due to Cost Pressures. Archive of Internal Medicine, 165 (15), 1749-1755.

Raju, P. S., Lonial, S. C. (2002). The Impact of Service Quality and Marketing on Financial Performance in the Hospital Industry: An Empirical Examination. Journal of Retailing and Consumer Services, 9, 335-348.

Ramsaran-Fowdar, R. R. (2008). The Relative Importance of Service Dimensions in a Healthcare Setting. International Journal of Health Care Quality Assurance, 21(1), 104-124.

Rehman, S. U., Nietert, P. J., Cope, D. W., Kilpatrick, A. O. (2005). What to Wear Today? Effect of Doctor's Attire on the Trust and Confidence of Patients. The American Journal of Medicine, 118, 1279-1286.

Reichheld, F., Sasser, W. E. (1990). Zero Defections: Quality Comes to Services, Harvard Business Review, 68, 105-111.

Reidenbach, R. E. (1990). Exploring Perceptions of Hospital Operations by a Modified SERVQUAL Approach. Journal of Health Care Marketing, 10 (4), 47-55.

Rhodes, R., Strain, J. J. (2000). Trust and Transforming Medical Institutions. Cambridge Quarterly of $\mathrm{He}$ althcare Ethics, 9, 205-217.

Riewpaiboon, W., Chuengsatiansup, K. Gilson, L., Tangcharoensathien, V. (2005). Private Obstetric Practice in a Public Hospital: Mythical Trust in Obstetric Care. Social Science \& Medicine, 61, 1408-1417.

Russell, S. (2005). Treatment-Seeking Behaviour in Urban Sri Lanka: Trusting the State, Trusting Private Providers. Social Science \& Medicine, 61, 1396-1407.

Ruyter, de K, Bloemer, J. M., Wetzels, M. G. (1998). On the Relationship between Perceived Service Quality, Service Loyalty and Switching Costs. International Journal of Service Industry Management, 9 (5), 436-453.
Sağlık Hizmetlerinde Önceliklerin Belirlenmesi: Türkiye'de Öncelik Belirleme Sürecinde Rol Alan Tarafların Görüşleri ve Sağlık Politikalarına İlişkin Değerlendirmeleri. Hacettepe Sağllk İdaresi Dergisi, $9(1), 93-123$.

Schermelleh-Engel, K., Moosbrugger, H., Müller, H. (2003). Evaluating the Fit of Structural Equation Models: Tests of Significance and Descriptive Goodness-of-Fit Measures. Methods of Psychological Research Online, 8 (2), 23-74.

Sharma, N., Patterson, P. G. (2000). Switching Costs, Alternative Attractiveness and Experience as Moderators of Relationship Commitment in Professional, Consumer Services. International Journal of Service Industry Management, 11 (5), 470-490.

Simonson, I., Drolet, A. (2004). Anchoring Effects on Consumers' Willingness-To-Pay and WillingnessTo-Accept. Journal of Consumer Research,31 (3), 681-690.

Sipahi, B., Yurtkoru, E. S., Çinko, M. (2006). Sosyal Bilimlerde SPSS ile Veri Analizi. Beta Basım A.Ş., İstanbul.

Sirdeshmukh, D., Singh, J., Sabol, B. (2002). Consumer Trust, Value, and Loyalty in Relationship Exchanges. Journal of Marketing, 66 (1), 15-37.

Siskou, O., Kaitelidou, D., Papakonstantinou, V., Liaropoulos, L. (2008). Private Health Expenditure in the Greek Health Care System: Where Truth Ends and the Myth Begins. Health Policy, 88, 282-293.

Sitzia, J., Wood, N. (1997). Patient Satisfaction: A Review of Issues and Concepts. Social Science \& Medicine, 45 (12), 1829-1843.

Smithy, C. (2005). Understanding Trust and Confidence: Two Paradigms and Their Significance for Health and Social Care. Journal of Applied Philosophy, 22 (3), 299-316.

Soyer, A. (2009). Sağlıkta Dönüşüm’ün Neresindeyiz? Bundan Sonra, Bizi Neler Bekliyor? Dokuz Eylül Üniversitesi Hemşirelik Yüksekokulu Elektronik Dergisi, 2 (4), 179-182.

Srinivasan, S. S., Anderson, R., Ponnavolu, K. (2002). Customer Loyalty in E-Commerce: An Exploration of Its Antecedents and Consequences. Journal of Retailing, 78, 41-50. 
Sülkü, S. N. (2011). Türkiye’de Sağlıkta Dönüşüm Programı Öncesi ve Sonrasında Sağlık Hizmetlerinin Sunumu, Finansmanı ve Sağllk Harcamaları. T.C. Maliye Bakanlığı Strateji Geliştirme Başkanlığı, Yayın No:2011/414, Ankara.

Şimşek, Ö. F. (2007). Yapısal Eşitlik Modellemesine Giriş Temel İlkeler ve LISREL Uygulamaları. Ekinoks Yayınları, Ankara.

Tanrıverdi, H., Erdem, Ş. (2010). Sağlık Hizmetlerinde Hizmet Kalitesi ile Tatmin Düzeyi Arasındaki İlişkinin İncelenmesi ve Bir Uygulama. Türkiye Sosyal Araştırmalar Dergisi, 14 (1), 73-92.

Tehrani, A. B., Feldman, S. R., Camacho, F. T., Balkrishnan, R. (2011). Patient Satisfaction with Outpatient Medical Care in the United States. Health Outcomes Research in Medicine, 2 (4), 197-202.

Temel, T. (2003). Özel Hastaneler Sektör Profili. İstanbul Ticaret Odası Yayınları, İstanbul.

Thiede, M. (2005). Information and Access to Health Care: Is There a Role for Trust? Social Science \& Medicine, 61, 1452-1462.

Thom, D. H., Kravitz, R. L., Bell, R. A., Krupat, E., Azari, R. (2002). Patient Trust in the Physician: Relationship to Patient Requests. Family Practice, 19 (5), 476-83.

Top, M., Tarcan, M., Tekingündüz, S., Güler, H. (2011). Yaşlılarda Hasta (Müşteri) Tatmininin Değerlendirmesi: İzmir İli Örneği. Hacettepe Üniversitesi Tüketici-Pazar-Araştırma-Danışma, Test ve Eğitim Merkezi Tüketici Yazıları (III), 100-141.

Tountas, Y., Karnaki, P., Pavi, E., Souliotis, K. (20005). The "Unexpected" Growth of the Private Health Sector in Greece. Health Policy, 74, 167-180.

Van der Schee, E., Braun, B., Calnan, M., Schnee, M., Groenewegen, P. P. (2007). Public trust in health care: A comparison of Germany, The Netherlands, and England and Wales. Health Policy, 81, 56-67.

Varinli, İ, Çakır, A. (2004). Hizmet Kalitesi, Değer, Hasta Tatmini ve Davranışsal Niyetler Arasındaki İlişkiKayserỉde Poliklinik Hastalarına Yönelik Bir Araştırma. Sosyal Bilimler Enstitüsü Dergisi, 17 (2), 33-52.

Verbeck, J. (2004). Patient Satisfaction: Is It a Measure for the Outcome of Care or the Process of Care? Journal of Clinical Epidemiology, 57, 217.
Vranceanu, A. M., Ring, D. (2011). Factors Associated With Patient Satisfaction. The Journal of Hand Surgery, 36 (9), 1504-1508.

Ware, J. E., Snyder, M. K., Wright, R., Davies, A. R. (1983). Defining and Measuring Patient Satisfaction with Medical Care. Evaluation and Program Planning, 6, 247-263.

Weisberg, J., Te’eni, D., Russo, M. L. A. (2011). Past Purchase and Intention to Purchase in e-commerce: The Mediation of Social Presence and Trust. Internet Research, 21 (1), 82-96.

Wertenbroch, K., Skiera, B. (2002). Measuring Consumers' Willingness to Pay at the Point of Purchase. Journal of Marketing Research, 39 (2), 228-241.

West, S.G., Finch, J. F., Curran, P. J. (1995). Structural Equation Models with Non-Normal Variables: Problems and Remedies, In R. Hoyle (Ed.), Structural Equation Modeling: Concepts, Issues and Applications, Newbury Park, CA: Sage, 56-75.

Wolfinbarger, M., Gilly, M. C. (2003) eTailQ: Dimensionalizing, Measuring and Predicting e-Tail Quality. Journal of Retailing, 79 (3), 183-198.

YASED (2012). Türkiye Sağlık Sektörü Raporu, Sürdürülebilir ve Kaliteli Bir Sağlık Sektörü için Genel Bakış ve Potansiyel İyileştirme Alanları (Haziran 2012), Deloitte, Türkiye, 104.

Yoo, B., Donthu, N. (2001). Developing a Scale to Measure the Perceived Quality of an Internet Shopping Site (SITEQUAL). Quarterly Journal of Electronic Commerce, 2 (1).

Zeithaml, V. A., Parasuraman, A., Malhotra, A. (2002). Service Quality Delivery Through Web Sites: A Critical Review of Extant Knowledge. Journal of the Academy of Marketing Science, 30 (Fall), 362-410.

Zeithaml, V. A., Berry, L. L., Parasuraman, A. (1996). The Behavioral Consequences of Service Quality. Journal of Marketing, 60 (2), 31- 46.

Zhang, J., Bloemer, J. M. M. (2009). The Impact of Value Congruence on Consumer-Service Brand Relationships. Journal of Service Research, 11 (2), 161-178. 
